تأثير أستخدام التدريب المركب على بعض مكونات التركيب الجسمى مكي وكثافة معادن عظام قدم الارتقاء لمتسابقى الوثب الثُلاثى لئى

"د/ عبد القادرالسيا مصطفى عوض الون

مقدمة ومشكلة البحث :

يشهـ العالم فى الآونة الأخيرة تقدماً علمياً ملحوظاً فى شتى مجالات

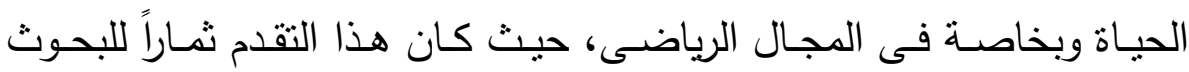

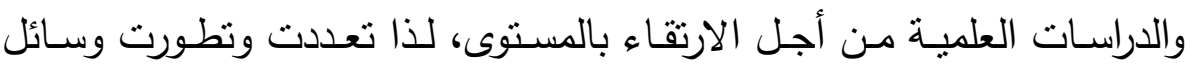

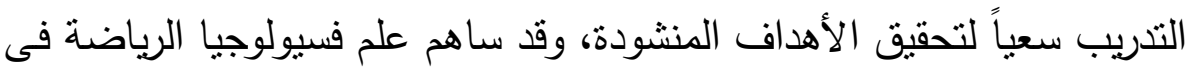

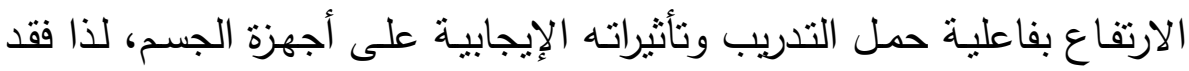
احتلت دراسة الاستجابات الفسيولوجية الناتجة عن بذل المجهود البدني كمثير

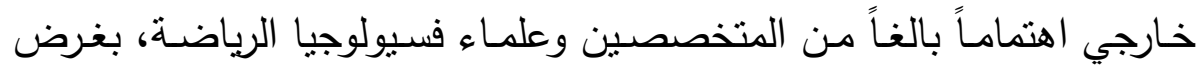
الوصول إلى أفضل استجابات فسيولوجية لتحقيق أفضل مستوى رياضي. ومسابقات الوثب من أنواع مسابقات الميدان التى تتميز بالسرعة والقوة فهي عبارة عن حركة وحيدة لها هدف واحد وغرض واحد ونهايـة واضحة ألا

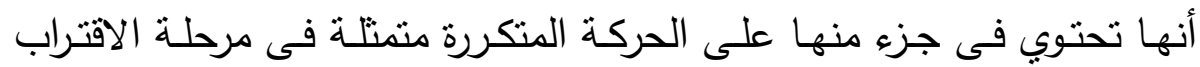
وتتمثل الحركة الوحيدة فى عملية الوثب الفعلية وهي الارتقاء والطيران والهبوط.

ويذكر "عبد الرحمن زاهر" (1 (1 + rم) أن التدريب الرياضي يؤدي إلي حدوث تغيرات فسيولوجية داخل الخلية العضلية بغرض إطلاق وإنتاج الطاقة اللازمة للأداء البدني ويتوقف مستوبي اللاعب علي مدي إيجابية هذة التغيرات بما يحقق التكيف لأجهزة الجسم لمواجهة الجهد والتعب الوظيفي والبدني الناتج

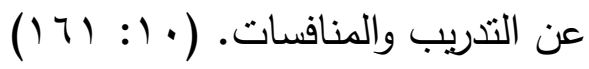

* أستاذ مساعد بقسم نظريات وتطبيقات مسابقات الميدان والمضمار بكلية التربية الرياضية مجلة أسيوط لعلوم وفنون التربية الرياضية

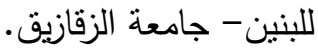


ولقد أستخدما حديثاً وعلي نطـاق واسـع التدريب البلومتري والتدريب

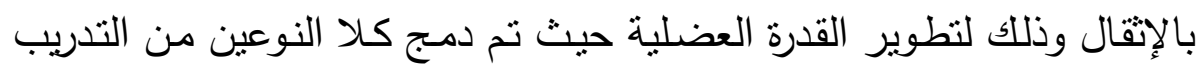

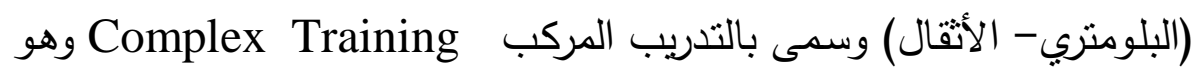

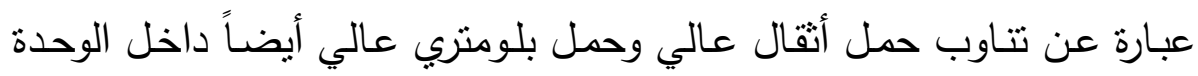
التدريبية الواحدة.(ع بانب

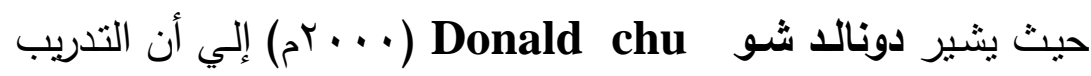
المركب أحد أنماط التدريب الرئيسية من قبّل الرياضيين ويستخدم فيه تدريبات

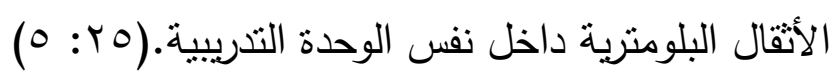

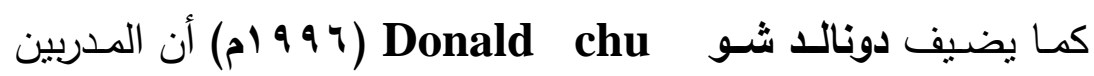

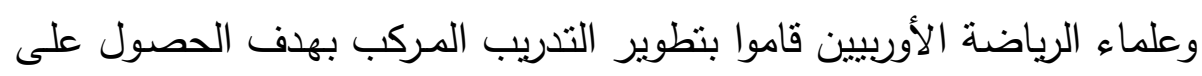

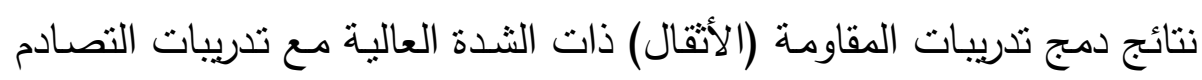

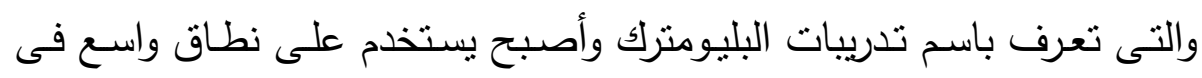

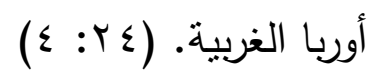

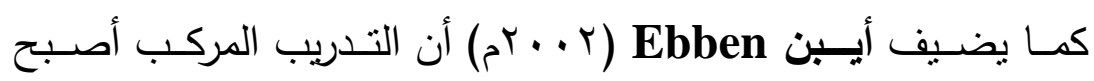

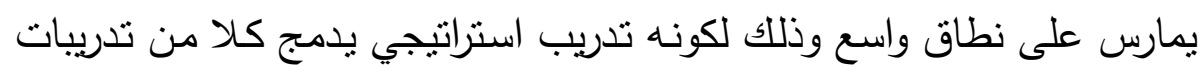

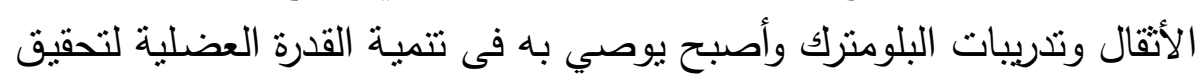

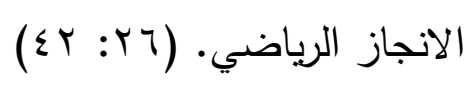

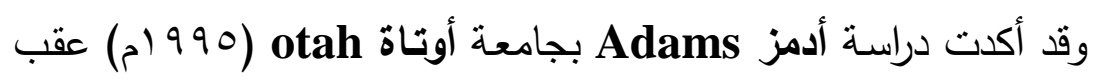

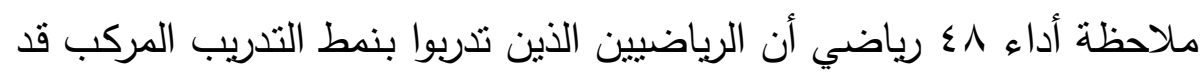

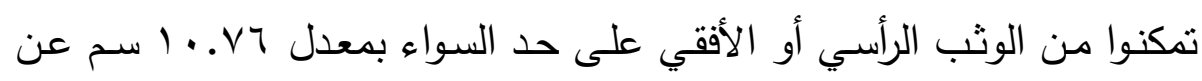

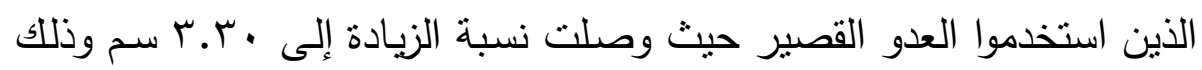

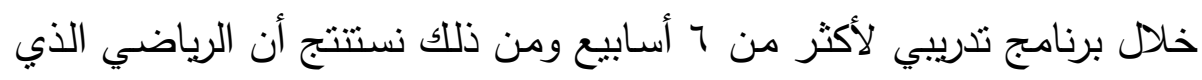

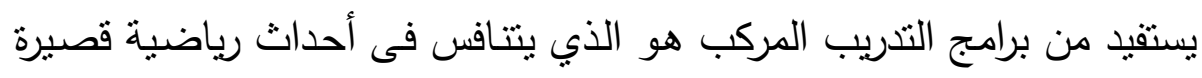

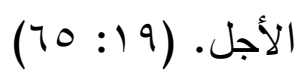

مجلة أسيوط لعلوم وفنون التربية الرياضية 
وقد اتفق معظم العلمـاء خـال المؤتمر الدولي للتندريب واللياقـة البنيـة

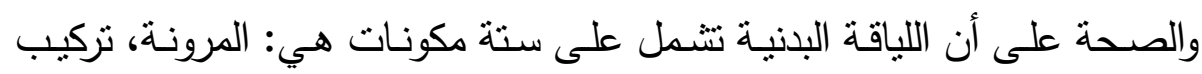

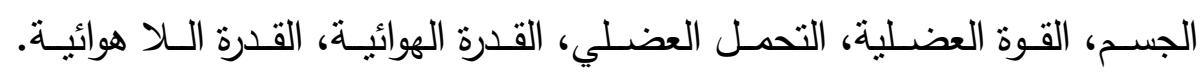
$(r 0: r)$

ويضـفى التـدريب الرياضـى المـنظم على شـكل الجســ تغيـرات وظيفيـة

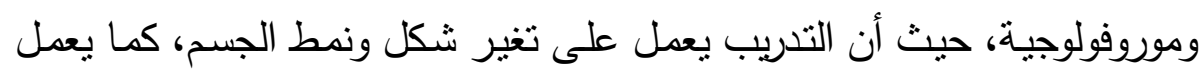

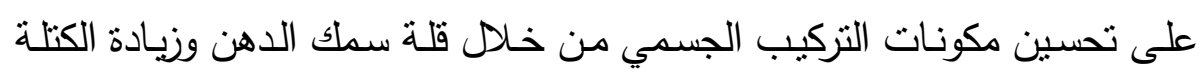

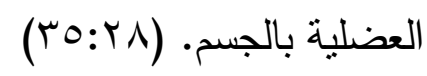
ويشير "أبو العلا أحمد عبد الفتاح، محمد صبحي حسانين" (99 (9 ام) أن تركيب الجسم Body compostion مصطلح يشير الى نسب وجود الأجزاء

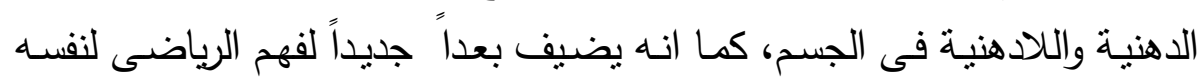

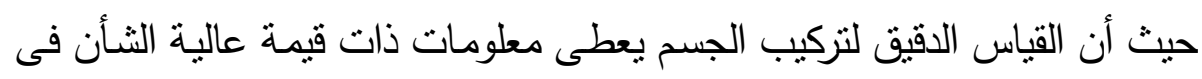
تحديد الوزن المثالي الذب يستطيع اللاعب عنده أن يصل الى الفورمة الرياضية.

(r)

كما يتفق كلاً من "أبو العلا أحمد عبد الفتاح، محمد صبحي حسانين

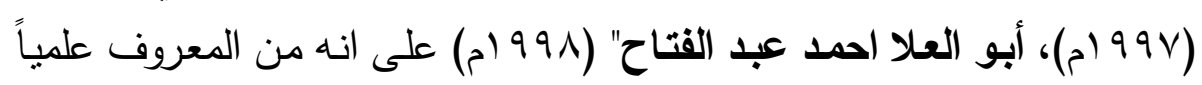

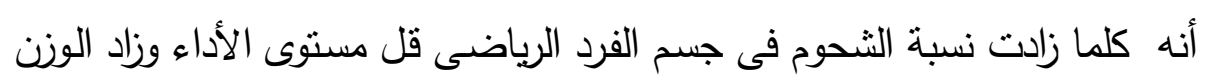

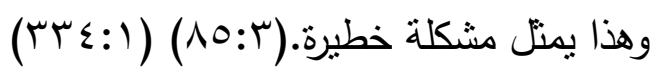

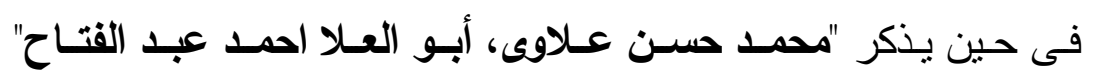

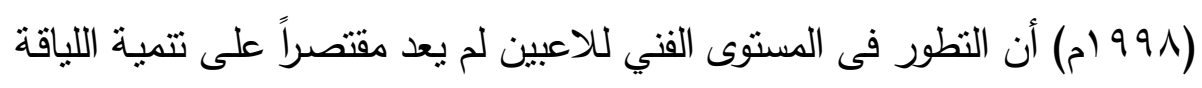

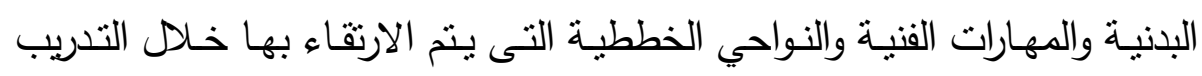

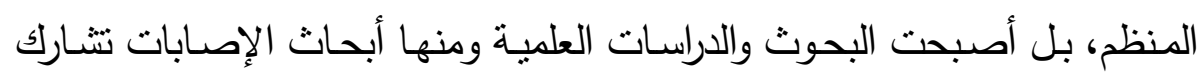

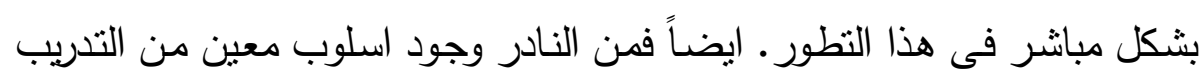

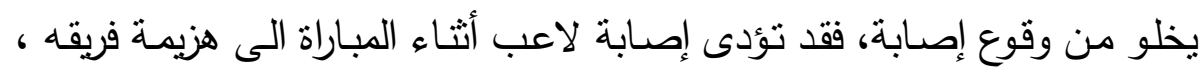

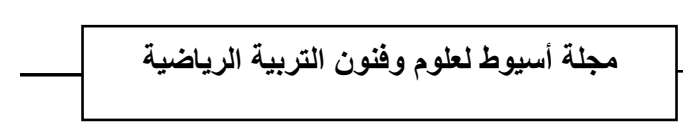




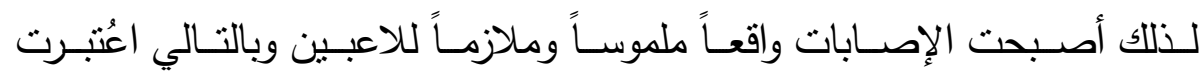

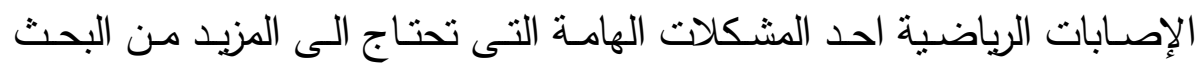

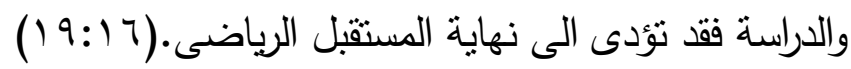

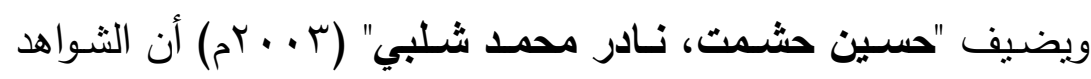

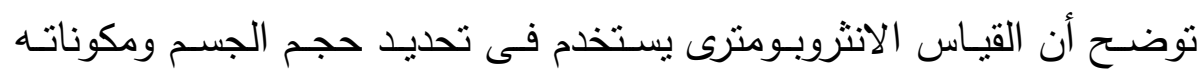

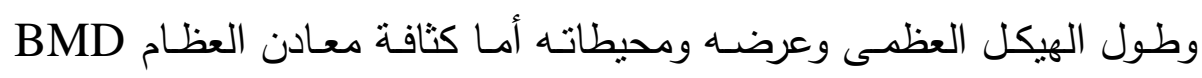

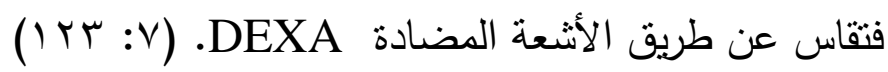

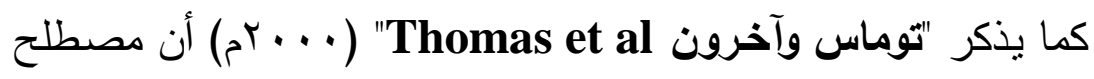
يعنى عتبة التحفيز التى تعتبر

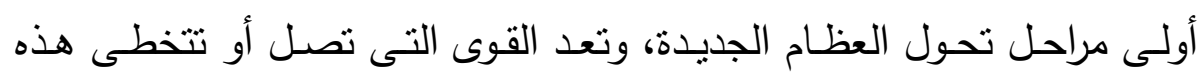

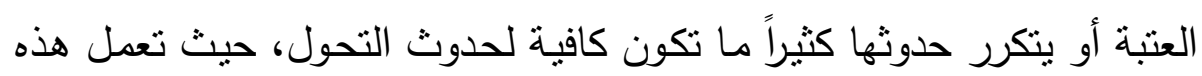

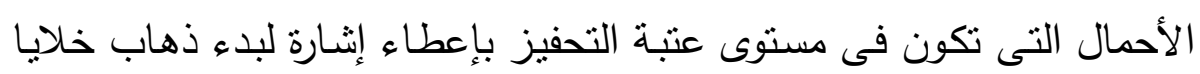
العظام Osteoblasts إلى تلك المناطق العظمية المتأثرة بتلك الأحمال، حيث العثاء

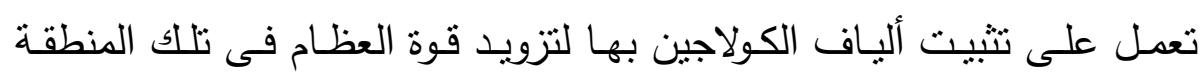

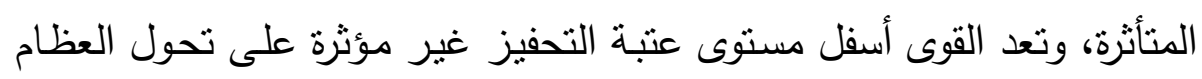

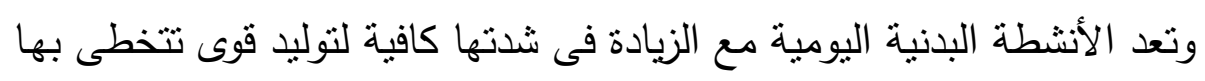

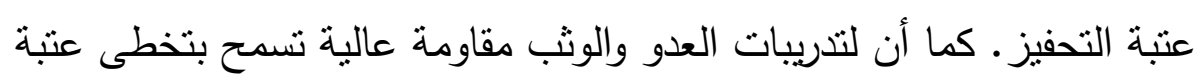
التحفيز، كذلك الأنشطة التى تتكل حمل لوزن الجسم على العظام مـع إضافة التهات

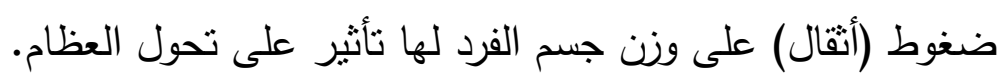

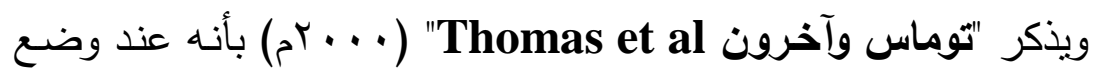

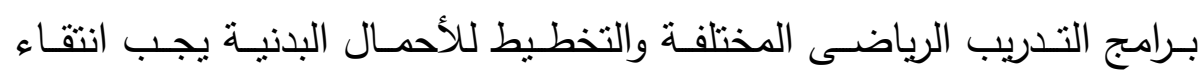

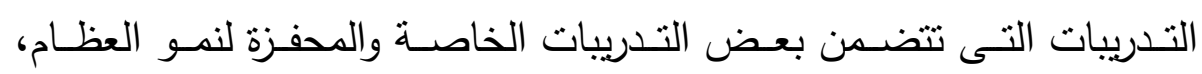

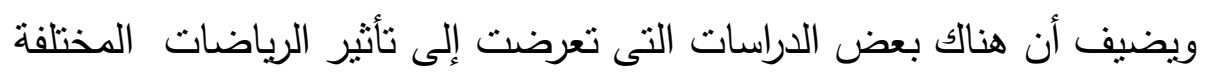

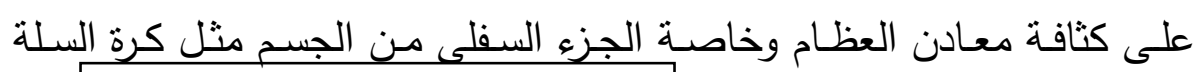
مجلة أسيوط لعلوم وفنون التربية الرياضية 
والكرة الطائرة والتدريبات على الأجهزة داخل الصالات حيث تم التعرف على الكى

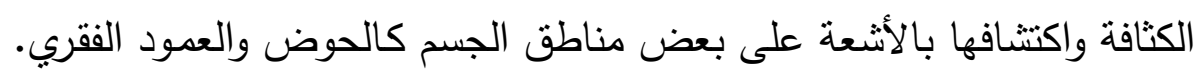

(7.67): (7)

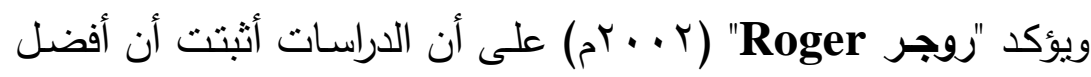

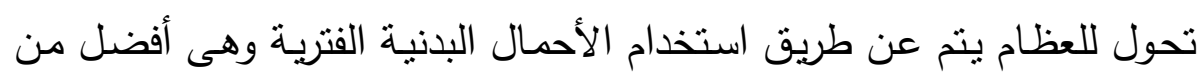
الأحمال البدنية المستمرة،علاوة على ذلك فإن القوى الكبيرة للمفاصل لها لها تأثيرها

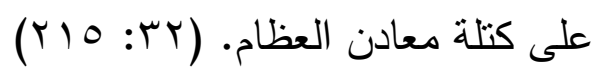

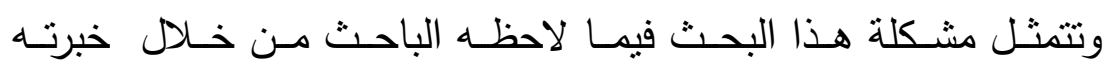

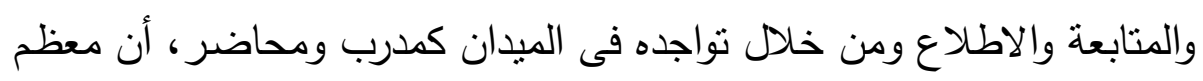

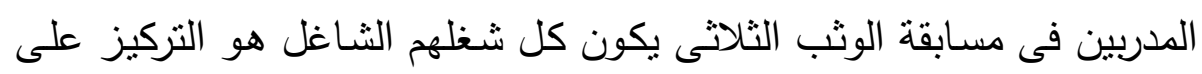

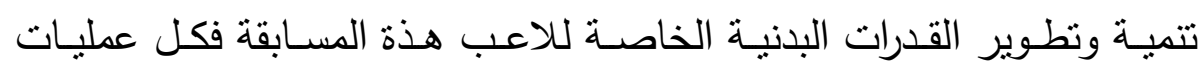
التدريب تقوم على تطوير تلك القدرات، بالأضافة الى انه قد ارتفعت الاحمال

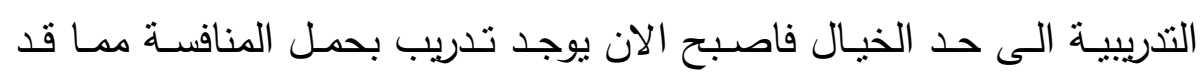

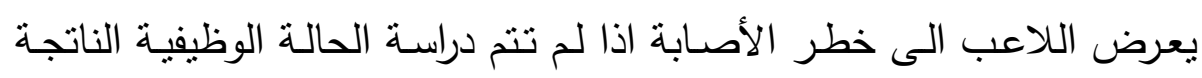

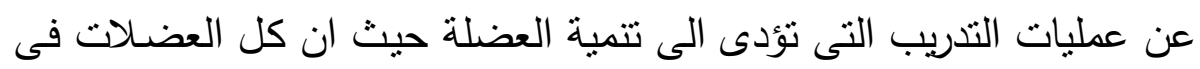

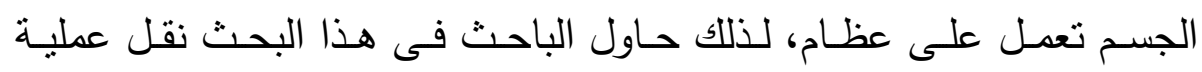

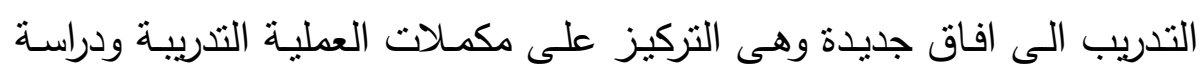

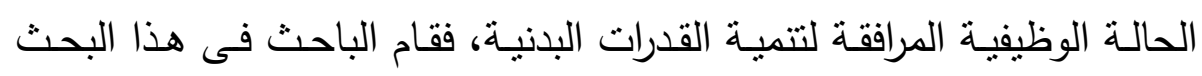

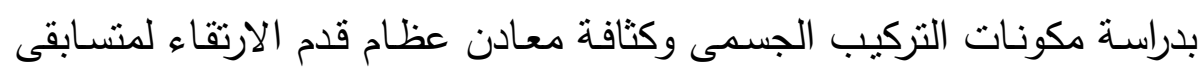

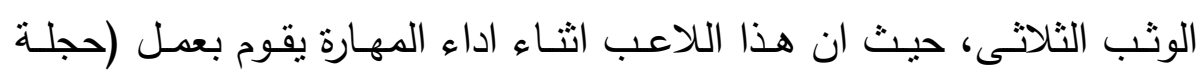

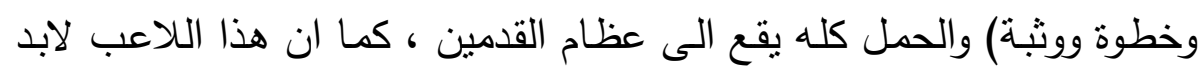

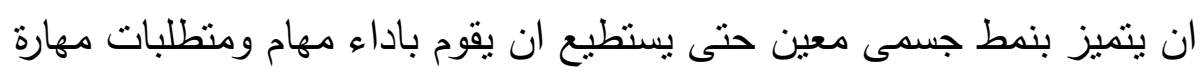
الوثب الثناثى بكفاءة عالية.

مجلة أسيوط لعلوم وفنون التربية الرياضية 
وهذا ما دفع الباحث لدراسة مكونات التركيب الجسمى وكثافة معادن عظام

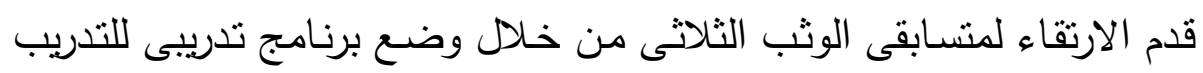

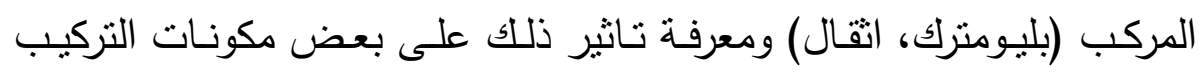

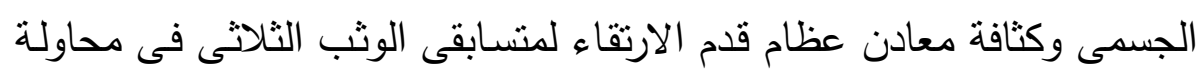
علمية لتطوير مهارة الوثب الثناثى. أهداف البحث : البطرير كهار

يهدف هذا البحث الى تصميم برنامج تدريبى مقترح للتدريب المركب

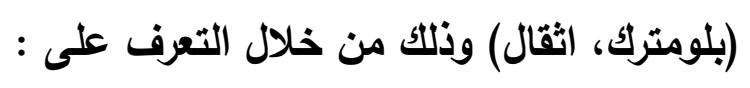

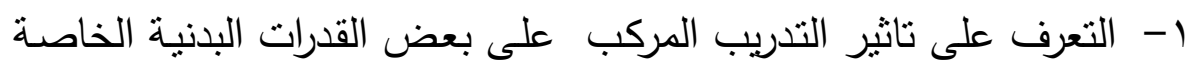

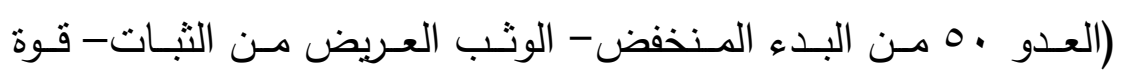

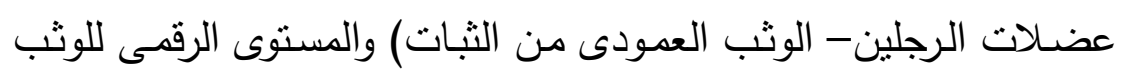

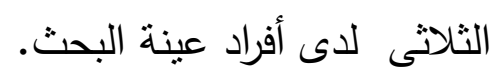

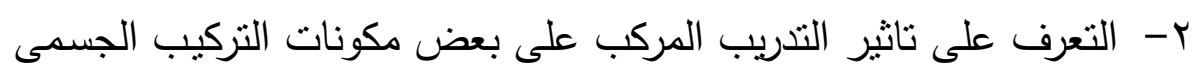

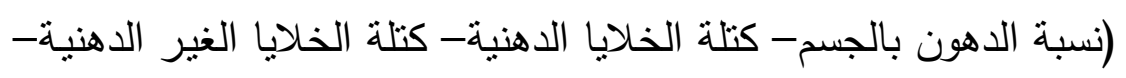

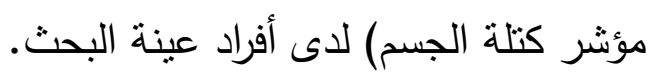

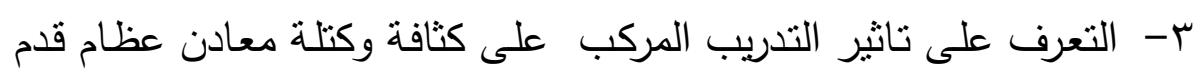
الارتقاء لدى أفراد عينة البحث.

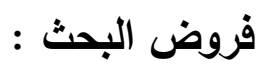

1- يؤثر التدريب المركب تأثثرا ايجابيا على بعض القدرات البدنية الخاصـة

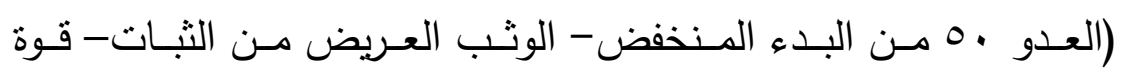

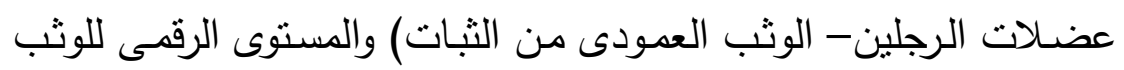
الثناثى لدى أفراد عينة البحث.

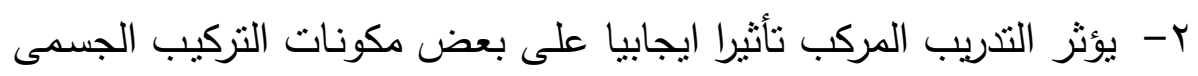
(نسبة الدهون بالجسم- كتلة الخلايا الدهنية- كتلة الخلايا الغير الدهنية-

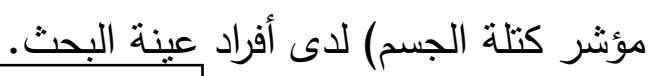
مجلة أسيوط للعوم وفنون التربية الرياضية 


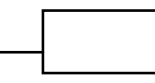

r- يؤثر التدريب المركب تأثيرا ايجابيا على كثافة وكتلة معادن عظام قدم

$$
\text { المصطلحات المستخدمة فى البحث: البراء عينة البحث. }
$$

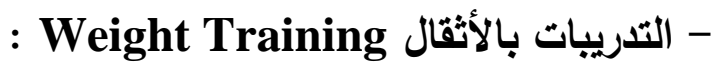

نظام للتدريب عبارة عن مجموعات من تمرينات المقاومـة المندرجة لإكساب :لإبات

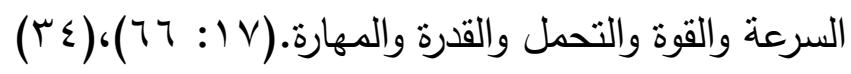

مكونات التركيب الجسمى Body Composition

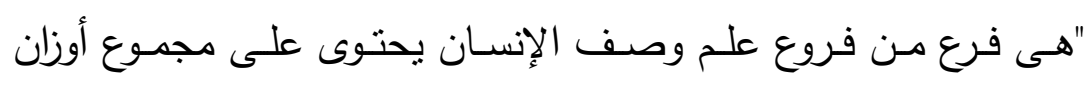

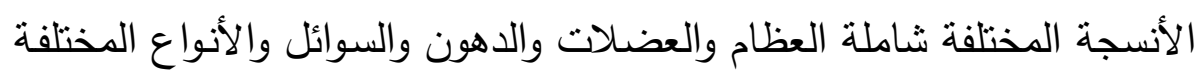

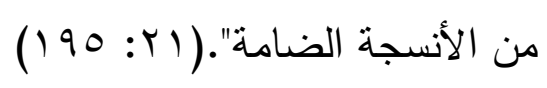

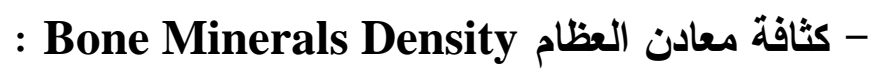
هى نسبة تركيز معادن العظام من الكالسيوم والفوسفور وهى مؤشر

$$
\text { لصلابة العظام. (ب0) }
$$

- Bone Minerals Mass كتلة معادن العظام ل هى صلابة العظام الناتجة عن وجود نسب المعادن بها. (ro)

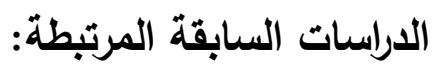

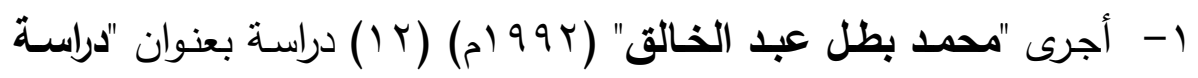
للقدرة العضلية للى لاعبى الوثب الطويل"، بهدف التعرف على العلى العلاقة

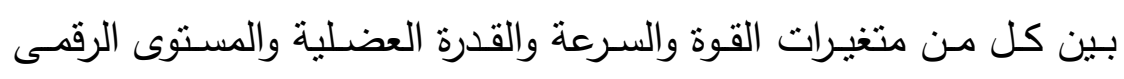
للوثب الطويل، والتعرف على العلاقة بين متغيرات القوة والسرعة الانتقالية

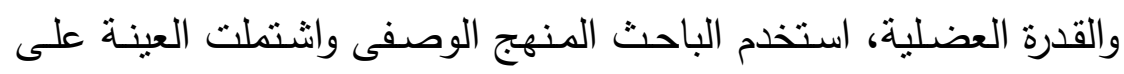

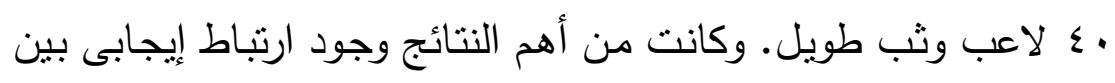

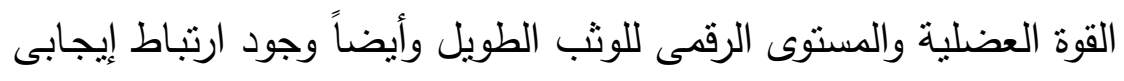

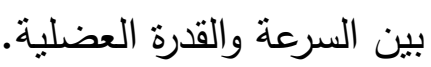
مجلة أسيوط للعوم وفنون التربية الرياضية 


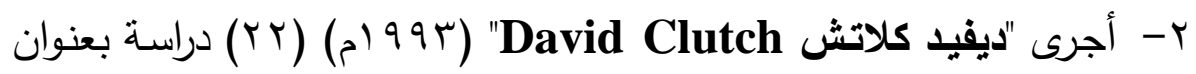

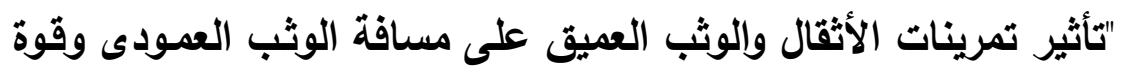

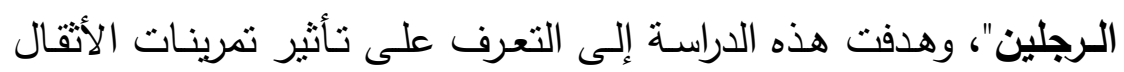

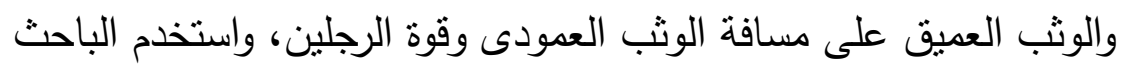

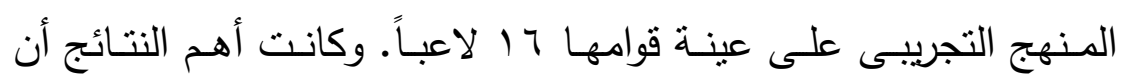

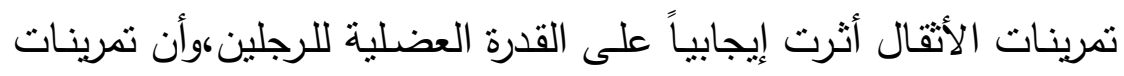
الوثب العمودى أثرت إيجابياً على القوة العضلية للرجلين.

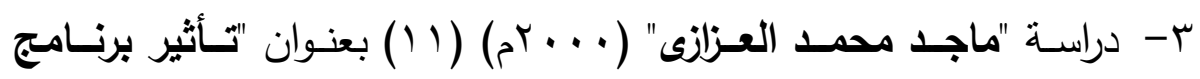

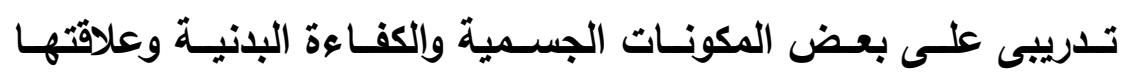

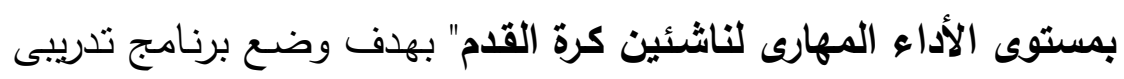

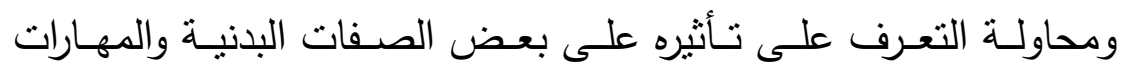

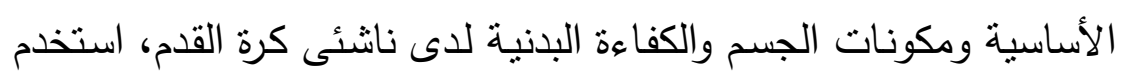

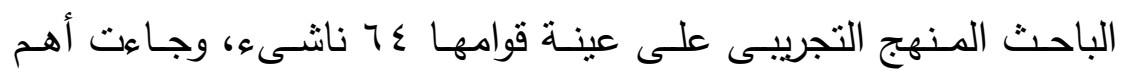

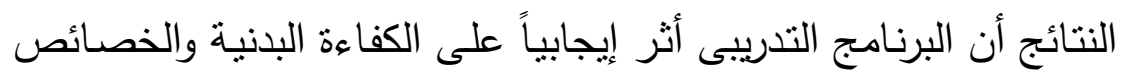

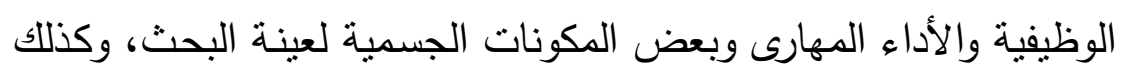

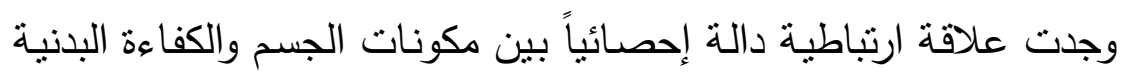
ومستوى الأداء المهارى لدى عينة البحث.

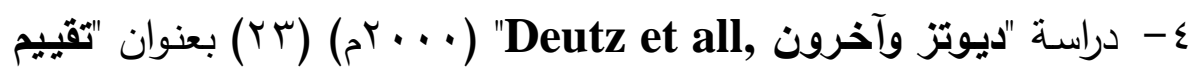

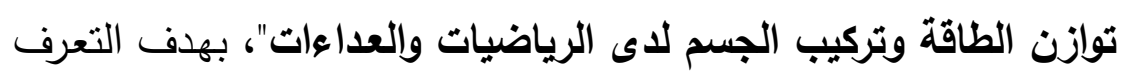

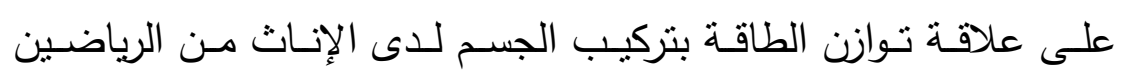

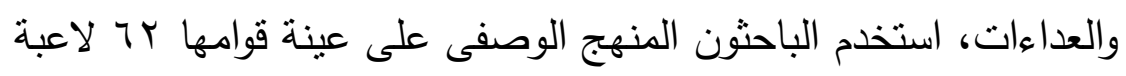

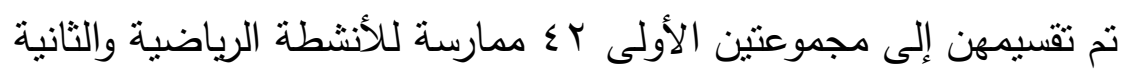
.

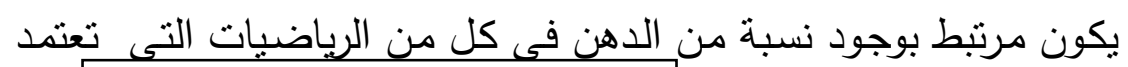
مجلة أسيوط لعلوم وفنون التربية الرياضية التبات 
على نظام الطاقة الهوائية واللاهوائية، وتوجد فروق دالة إحصائياً بين ناقص وفائض الطاقة لكل من الرياضيات والعداءات ولصالح العداءات.

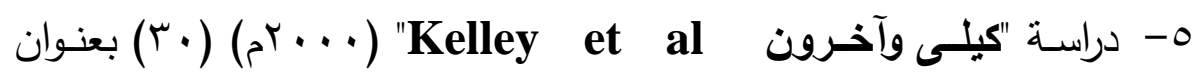
"التدريبات وكثافة معادن العظام للدى الرجال" بهدف التعرف على تأثير

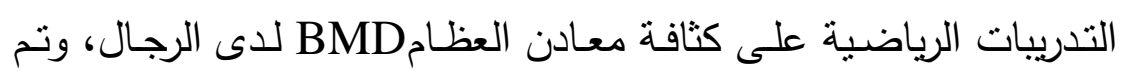

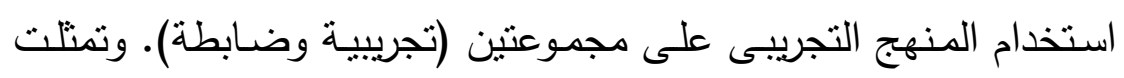

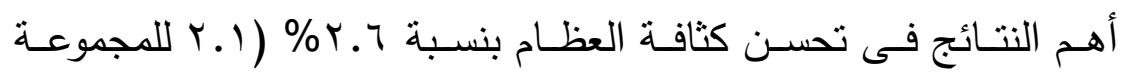
التجريبة، ه. • للمجموعة الضابطة).

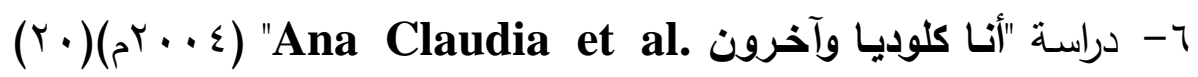

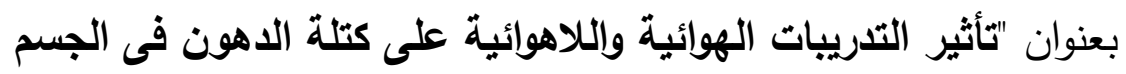

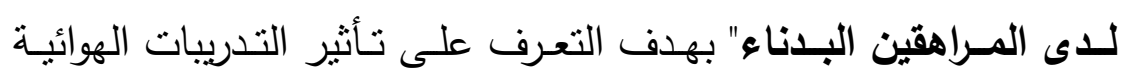

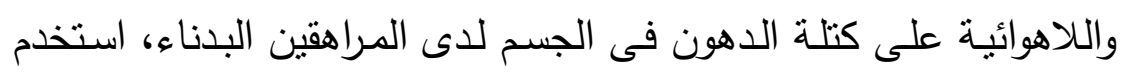

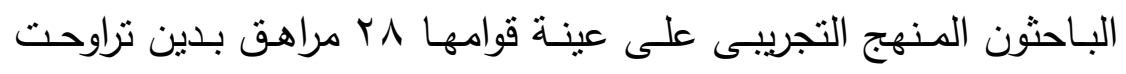

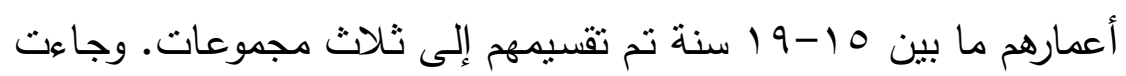

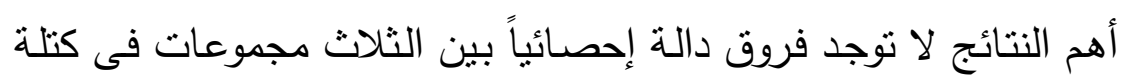

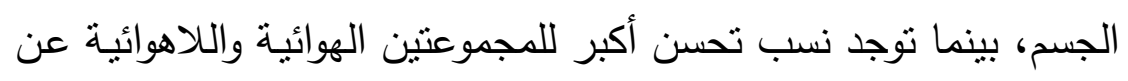
المجموعة الضابطة. - V أجرى "أيمـن أحمد عبد الفتـاح الباسطى" (0 . . rم) (7) دراسـة بعنوان

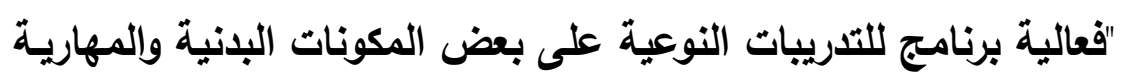

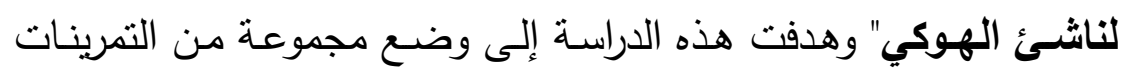

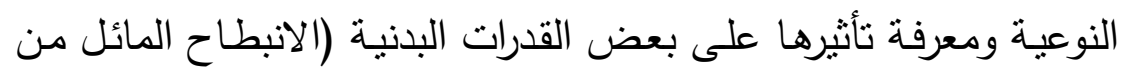

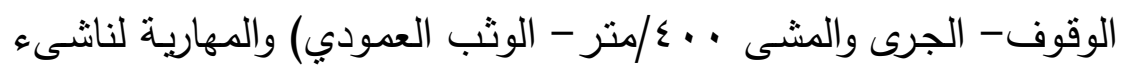

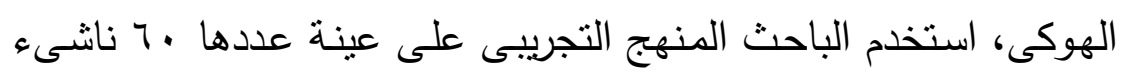

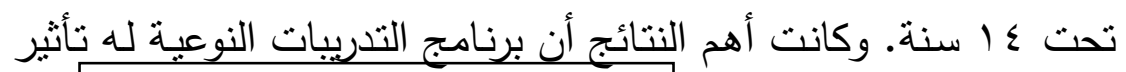
مجلة أسيوط لعلوم وفنون التربية الرياضية لإعية لينات 


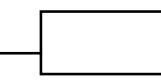

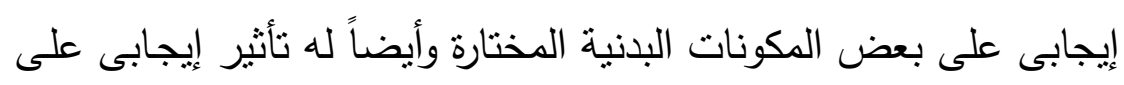
بعض المكونات المهارية المختارة.

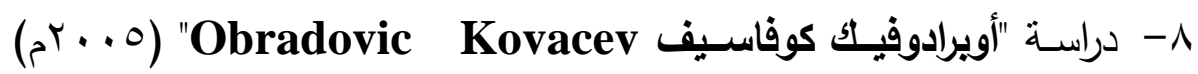

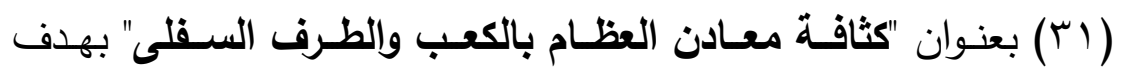

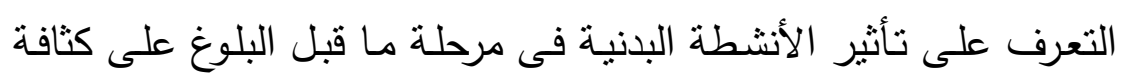

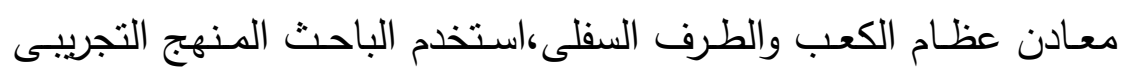

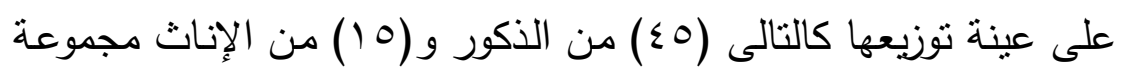

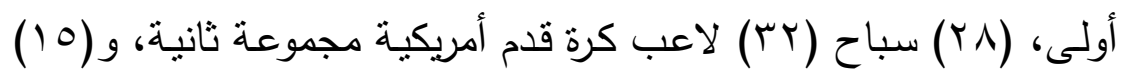

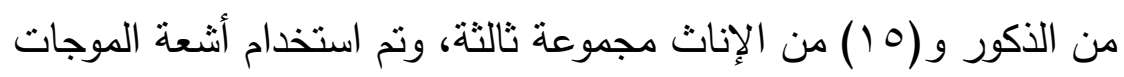
فوق الصوتية لكثافة معادن العظام لكل من كعب القدم الأيمن والأيسر .

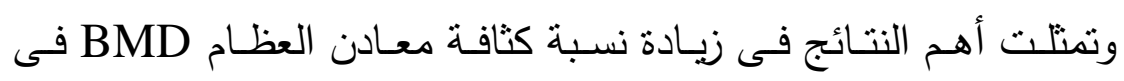
الأطراف النى بيتخدمها الرياضيين فى ممارسة أنشطتهم البدنية.

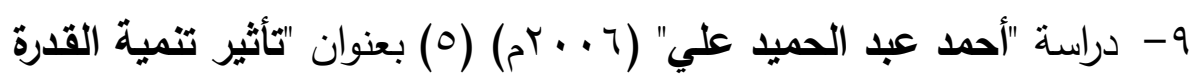

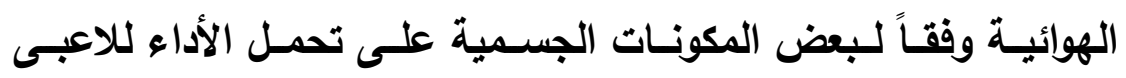

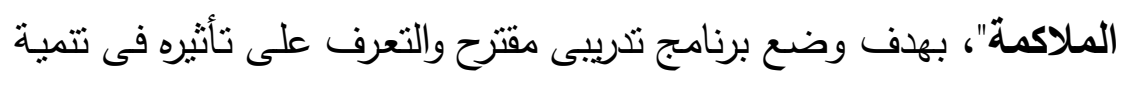

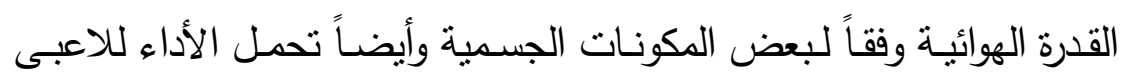

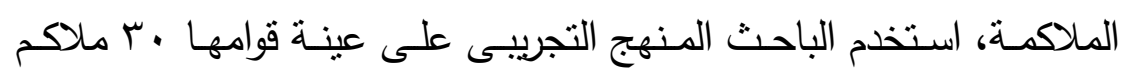

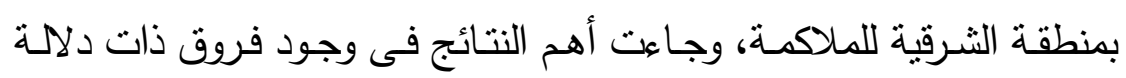

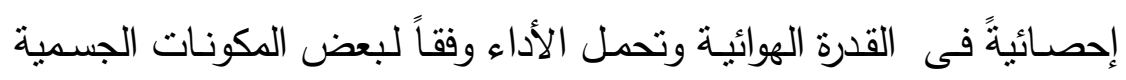
لاى أفراد عينة البحث بين القياسين القبلى والبعدى.

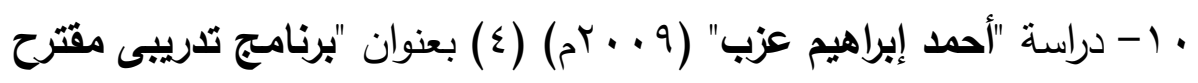

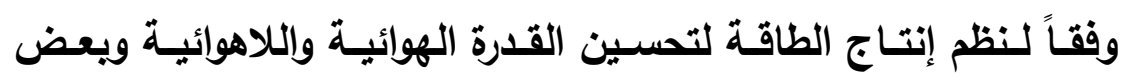
المتغيـرات البذنيـة وإلتكوين الجسـى للاعبـى المبـارزة" بهدف تصميم 
برنـامج تدريبى مقترح وفقاً لنظم إنتاج الطاقة والتعرف على تأثيره على

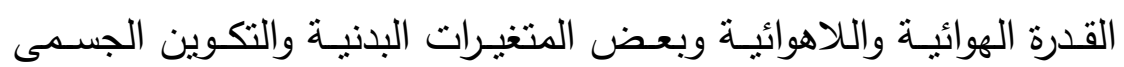
للاعبى المبارزة، استخدم الباحث المنهج التجريبى على عينة قوامها مبه لاعـب، وكانـت أهــ النتـائج تحسـن دال إحصــائياً فـى القـدرة الهوائيـة واللاهوائية بين القياسين القبلى والبعدى ولصسالح القياس البعدى، وأيضـاً فـى بعـض المتغيـرات البدنيـة (تحمـل القـوة المميـزة بالسـرعة- التحمـل العضـلي- الدقة- الرشـاقة- التوافق) بالإضـافة إلى انخفاض وزن الدهن وكذللك وزن الجسم وزيادة النسيج العضلى. إجراءات البحث: منهج البحث : اسـتخدم الباحـث المـنهج التجريبـى بتصـميم القبـاس القبلـى والبعـدى لمجموعة تجريبية واحدة وذلك لملاعمنه لطبيعة الدراسة. عينة البحث:

تم اختيار عينة البحث من متسـابقى الوثب الثلاثى والمسجلين بالاتجاد المصرى لألعاب القوى بنادى كفر صقر الرياضىى التابع الى مدريرية الثباب

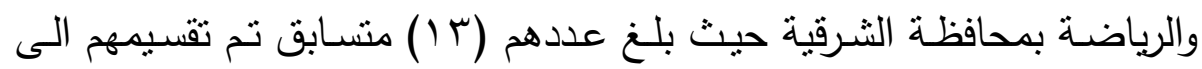
(^) متسـابقين عينـه اساسية للبحـث، بالأضـافة الى (0) متسـابقين للتجربـة الاستطلاعية. والجدول التالى رقم (1) يوضح توصيف عينة البحث.

\begin{tabular}{|c|c|c|c|c|c|c|}
\hline \multicolumn{2}{|c|}{ عينة البحث الكلية } & \multicolumn{2}{|c|}{ عينة البحث الأساسية } & \multicolumn{2}{|c|}{ عينة البحث الاستطلاعية } & \multirow{2}{*}{ البحتم } \\
\hline النسبة \% & 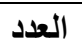 & النسبة \% & العدد & النسبة \% & العدد & \\
\hline
\end{tabular}




\begin{tabular}{|l|l|l|l|l|l|l}
\hline \hline $1 \cdots$ & 1 & $\pi, 0$ & $\Lambda$ & $\mu \Lambda, 0$ & 0 & $1 \mu$ \\
\hline \hline
\end{tabular}

يتضـح مـن الجدول رقم ( (1) أن العينـة الكليـة للبحث (س أ) متشـابق

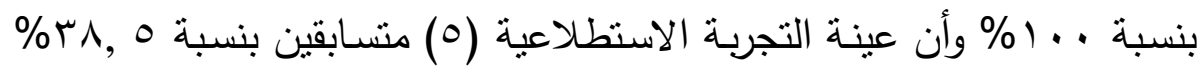

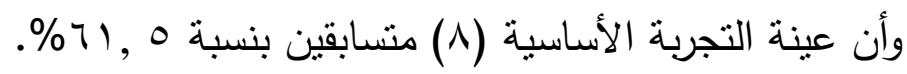

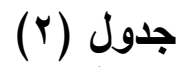

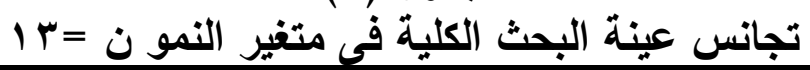

\begin{tabular}{|c|c|c|c|c|c|c|}
\hline الالتواء معامل & التقلطح معامل & الوسيط & المعيارى & الحسابى & القياس & المتغيرات \\
\hline .. & $\cdot . \wedge r-$ & $7 \ldots$ &. $.9 \mathrm{~V}$ & $7 . .11$ & كجم & الوزن \\
\hline. .99 & . & $171 \ldots$ & $1 . \leqslant 1$ & 171.59 & سم & الطول \\
\hline r.. o & $1 . Y M-$ & 10.0. &..$Y Y$ & 10.70 & سنة & العمر \\
\hline..$r Y$ & 1.11 & $7 . V$. & $1 . . r$ & 7.09 & سنه & العمر التدريبي \\
\hline
\end{tabular}

يتضـح من جدول (Y) ان قيم معامالات الالتواء تقع مـا بين +با، مما

يدل على أن جميع أفراد العينة كانوا تحت المنحنى الاعتدالى فى (الوزن-

الطول- العمر ) مما يشير إلى تجانس أفراد عينة البحث فى متغيرات النمو .

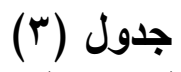

تجانس عينة البحث الكلية فى القدرات البذنية والمستوى الرقمى قيد البحث

$$
1 \mu=\dot{0}
$$

\begin{tabular}{|c|c|c|c|c|c|c|}
\hline الالتواء & التقلطح & الوسيط & الالنعرافيارى & المستوسطى & القياس & المتغيرات \\
\hline $.7 .-$ & $1 . r 1-$ & $7 . \leqslant Y$ & $\ldots 0$ & १.\&1 & ثانية & البدء المنخفض من \\
\hline 1.0. & $1.7 \mathrm{r}-$ & 1.1. & $\ldots \varepsilon$ & l.Ar & سم & الون الثريض \\
\hline
\end{tabular}

تابع جدول (r)

تجانس عينة البحث الكلية فى القدرات البدنية والمستوى الرقمى قيد البحث

\begin{tabular}{|c|c|c|c|c|c|c|}
\hline الالتواء & التقلطح & الوسيط & الالمعيارى افى & الحستوسطي & القياس & المتغيرات \\
\hline
\end{tabular}

$$
1 \mathrm{H}=\dot{0}
$$
مجلة أسيوط لعلوم وفنون التربية الرياضية 


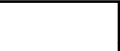

\begin{tabular}{|c|c|c|c|c|c|c|}
\hline $.7 V-$ & $1.1 \mathrm{r}-$ & ४^... & $r . . v$ & $7 V .0 \leq$ & ثقل/كجم & قوة عضلات \\
\hline .99 & $1.0 .-$ & rr... & 1.19 & rr.rA & سم & الوثب العمودى الثبات \\
\hline.$V 0$ & 1.rr- & $11 . r$ & $\ldots \wedge$ & 11.2. & متر & للوثب الثستوى الرقىى \\
\hline
\end{tabular}

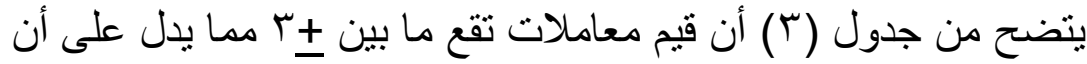
جميع أفر اد العينة كانوا تحت المنحنى الاعتدالى فى القدرات البدنية والمستوى

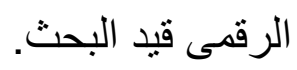

\section{جدول (飞)}

تجانس عينة البحث الكلية في متفيرات مكونات التركيب الجسمي والمستوي

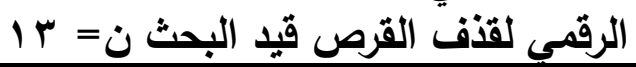

\begin{tabular}{|c|c|c|c|c|c|c|}
\hline الالتواء & الوسيط & الانحراف المعياري & المستوسطي & والقياس & المتغير ات & r \\
\hline $\begin{array}{c}- \\
. .1 \varepsilon\end{array}$ & 11.19 &.$Y_{1}$ & 11.9. & $\%$ & نسبة الدهون بالجسم & 1 \\
\hline .011 & V.AT & .00 & 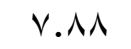 & كجم & كتلة الخلايا الدهنية & $r$ \\
\hline$\ldots V$ & $\leq 0 . \leqslant 1$ &..$\leqslant 0$ & $\leqslant 0 . \leqslant Y$ & كجم & كتلة الخلايا غير الدهنية & $r$ \\
\hline r.lr & r...r & $.0 \%$ & $r . .7$. & كجم/ar & مؤشر كنلة الجسم & $\varepsilon$ \\
\hline
\end{tabular}

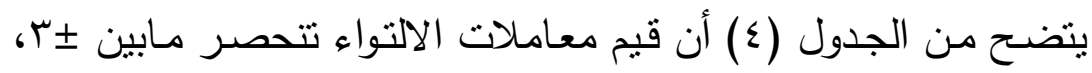

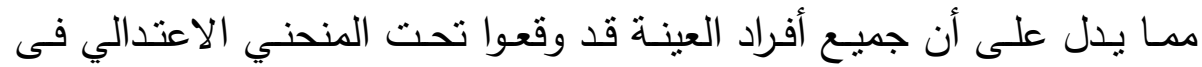
متغيرات مكونات التركيب الجسمى مما بدل على تجانس أفراد عينة البحث فى لى لئ تلك المتغيرات.

\section{جدول (0)}

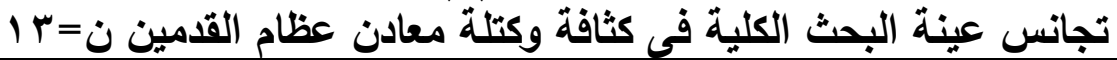

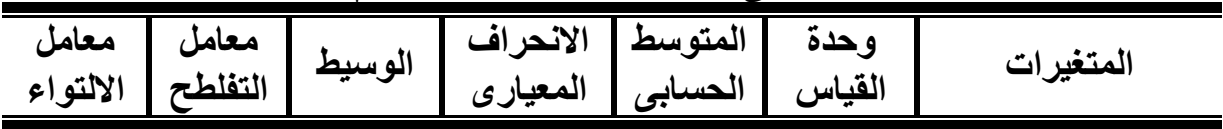
مجلة أسيوط لعلوم وفنون التربية الرياضية 


\begin{tabular}{|c|c|c|c|c|c|c|}
\hline r... & $\because V V-$ & $1 . .1 \mathrm{~V}$ & .... & $1 . .19$ & $\mathrm{~g} / \mathrm{cm}^{2}$ & الفخذ عنق عظم \\
\hline .7 & I.Ar- & .1107 & $\ldots .0$ &.$\wedge \circ \mathrm{V}$ & $\mathrm{g} / \mathrm{cm}^{2}$ & $\begin{array}{c}\text { BMD } \\
\text { الكبير BMر }\end{array}$ \\
\hline . Vo & $. \vee \vee \wedge-$ &.$V E r$ & $\cdots \wedge$ & $. V \leqslant \leq$ & $\mathrm{g} / \mathrm{cm}^{2}$ & $\begin{array}{c}\text { Wards Tri } \\
\text { BMD }\end{array}$ \\
\hline $1.0 \mathrm{~V}$ & $1 . V \leqslant-$ & צ.M &..$Y_{1}$ & $\varepsilon . \varepsilon V$ & g & 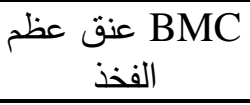 \\
\hline. Vo & 1. $1 \leq-$ & 11.71 & $\cdot . \wedge$ & 11.7 & g & $\begin{array}{c}\text { BMC } \\
\text { المدور }\end{array}$ \\
\hline $.911-$ & $1.90-$ &..$\wedge 1$ & $\cdots \cdot 1$ &.$\Lambda$. & g & $\begin{array}{c}\text { Wards Tri } \\
\text { BMC }\end{array}$ \\
\hline
\end{tabular}

يتضح من الجدول (0) أن قيم معاملات الالتواء تقع ما بين + ب، مما يدل على أن جميع أفراد العينة قد وقعوا تحت المنحنى الاعتدالى فى كثافة وكتلة معادن عظام قدم الارتقاء لمتسابقى الوثب الثلاثى. أدوات جمع البيانات والاجهزة المستخدمة: أولاً: الأجهزة والأدوات المستخدمة لقياس متغيرات البحث:

- جهاز رستامينز لقياس الطول. مرفق رقم (1) - ميزان طبى معاير لقياس الوزن. مرفق رقم (r) - شربط قياس. - مياعة إيقاف رقمية. - جهاز الديناموميتر لقياس قوة عضلات الرجلين. - جهاز DEXA بالأشعة المضادة لقياس كثافة وكتلة العظام. وهو عباره عن منضده يتحرك عليها افقياً جهاز الأشعة منصلة بجهاز كمبيوتز كوحدة أخراج للبيانات الخاصة بكثافة وكتلة معادن العظام. - جهاز تحليل مكونات الجسم الأكترونى طراز تانيتا مرفق (V) - أعلام وأقماع وعلامات ضابطة. - جهاز كمبيوتر بمشتملاته. مجلة أسيوط لطوم وفنون التربية الرياضية 
- صديري أثقال بأوزان مختلفة بما لا يتعدى ب كجم. - الجيتز (أكياس قماثية تملئ رمل) بأوزان مختلفة بما لا تتعدى سكجم. ثانياً: الاختبارات البدنية المستخدمة فى البحث: بعد الاطلاع على الدراسات المرتبطة بموضوع البحث ومختلف المراجع

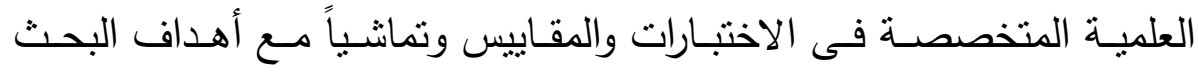
توصـل الباحث إلى مجموعـه مـن الاختبـارات لقياس القدرات البدنيـة الخاصـة بمتسابقى الوثب الثلاثى بالإضـافة إلى قياس المستوى الرقمي للوثب الثالاتى

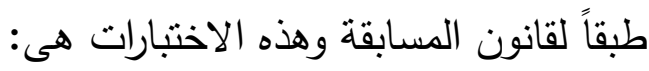

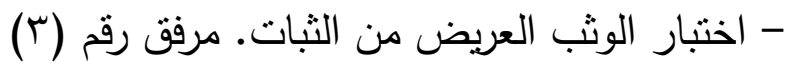

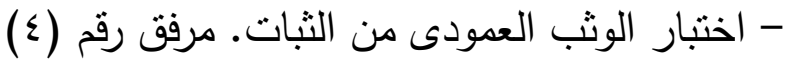
- اختبار قياس قوة عضلات الرجلين بالدينامومينز • مرفق رقم (0) - اختبار • 0م عدو من البدء المنخفض. - قياس مكونات التركيب الجسمى: لقيـاس مكونـات التركيـب الجســى اسـتخدم الباحـث طريقـة الكهربـاء

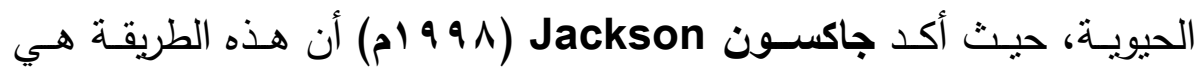
إحــدى الطــرق الرئيسـية لمعرفــة المكونـات والمتغيـرات الداخليــة للفـرد. $(7 \vee: Y q)$

وقد استخدم الباحث جهاز تحليـل مكونـات الجسـم الأكترونى طـراز تانيتا (Tanita410 TBF)، مرفق (V) حيث يقف المختبر على هذا الجهاز مباشرة ليمر تيار كهربائي يتراوح ما بين . .0- . . . أمبير / • . كيلو هيرتز

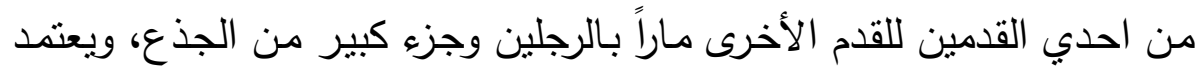
التوصيل الكهربائي خلال الأنسجة بين الأقطاب (القدمين) على توزيـع الماء والأملاح المعدنية فى هذه الأنسجة، ونتيجة لاحتواء هذه الأنسجة غير الدهنية مجلة أسيوط لعلوم وفنون التربية الرياضية الإنية 
على نسبة كبيرة من ماء الجسم بعكس الأنسجة الدهنية التى تحتوى على نسبة قليلة ، ونتيجة لذلك تكون عملية التوصيل الكهربائي أكثر وأسرع في الأنسجة الغير دهنية مقارنة بالأنسجة الدهنية، وبناءاً على ذلك فأن كمية التيار الساري خلا الأنسجة يعبر عن الكمية النسبية لمحتوى الدهون ومن ثم يمكن الحصول على بيانات تدل على تركيب جسم المختبر · (rv) - متغيرات مكونات التركيب الجسمى التى تم قياسها : - نسبة الدهون الكلية بالجسم Fat -

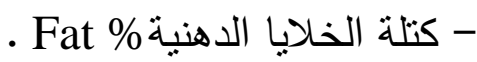

- Fat free masss كتلة الخلايا غير الدهنية - مؤشر كتلة الجسم Body Mass Index. - قياسات كثافة وكتلة معادن العظام باستخدام جهاز DEXA. مرفق رقم

* كثافة معادن عظام قدم الارتقاء: حيث تم قياس الكثافة فى المناطق الآتية:

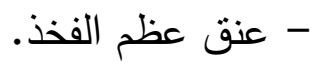

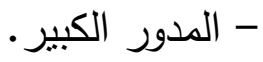

Wards Tri (عظم واردس المنلثي) * كتلة معادن عظام قدم الارتقاء: حيث تم قياس الكتلة فى الآتي:

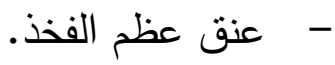
- المدور الكبير -

Wards Tri (عظم واردس المنظلي) ثالثاً: البرنامج التدريبي المقترح: مرفق رقم (9) الهدف من البرنامج :

وضع مجموعة من التدريبات المركبة (بلومنرك، اثقال) وذللك لتطوير بعض من

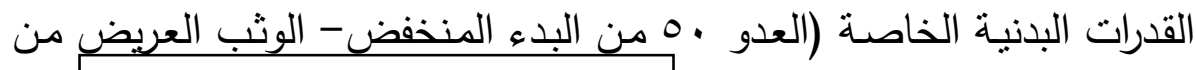
مجلة أسيوط لطوم وفنون التربية الرياضية 
الثبات- قوة عضـلات الرجلين- الوثب العمودى من الثبات) والمستوى الرقمى للوثب الثلاتثى، وتطـوير بعض مكونـات التركيـب الجسـمى (نسبة الـدهون

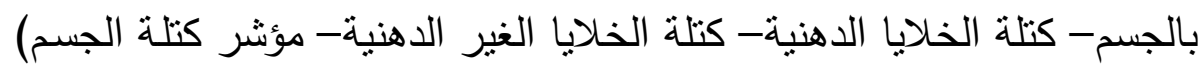
وكذلك التاثير الايجابى على كثافة وكتلة معادن عظام قدم الارتقاء لدى أفراد عينة البحث.

أسس وضع البرنامج التدريبى وفقا لخصائص المرحلة السنية لعينة البحث: - - تم مراعاة أن يوضع البرنامج التدريبي وفقاً للقدرات البدنية والوظيفية لأفراد عينة البحث.

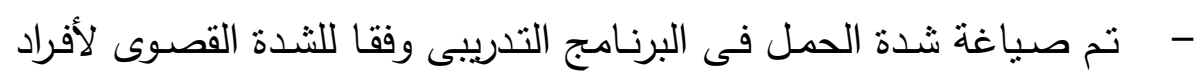
عينـة البحث وبطربقـة فرديـة وعلى حسب قدرات كل لاعب مـن افراد العينة.

- مراعـاة البرنـامج لعوامل الامـن والسـلامة وان يكون قابـل للتعديل ويتميز بالمرونة.

- - أن يراعى البرنامج القدرات الفردية لكل لاعب من افراد عينة البحث.

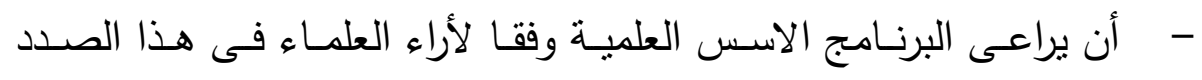

$$
\text { (التذريب المركب). }
$$

- - أن يراعى البرنامج الاسس العلمية فى تدريبات الاثقال والبلومترك.

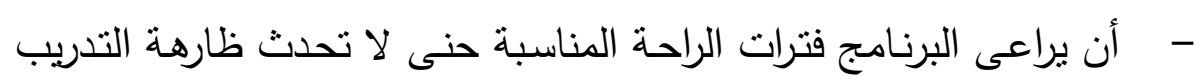
الزائد لاى افراد عينة البحث. لئ.

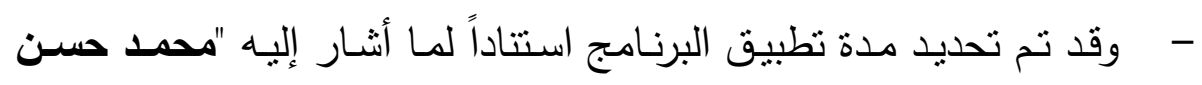

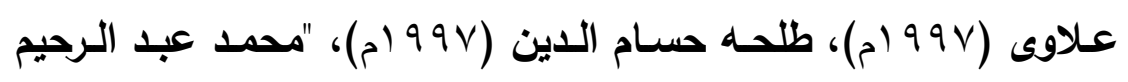

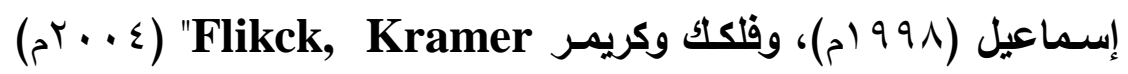
أن التدريب المركب والذى يهدف الـى تطـوير القوة العضـلية باسـتخدام الاثقال والبلومترك لا يحدث نتاائج سريعه وأن التدريب لعدة أسابيع يساهم مجلة أسيوط لعلوم وفنون التربية الرياضية لعدة التياية 


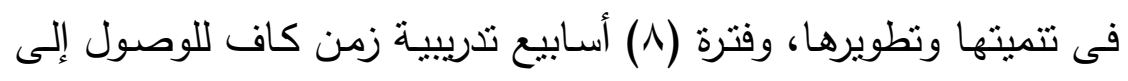

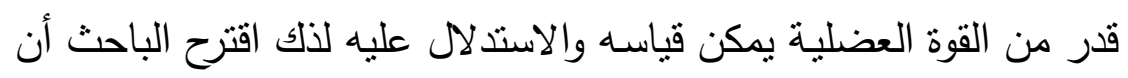

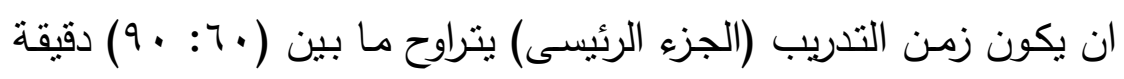

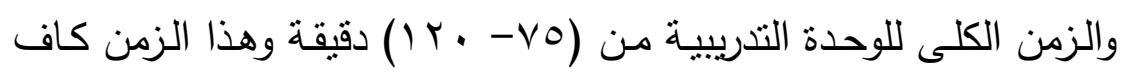

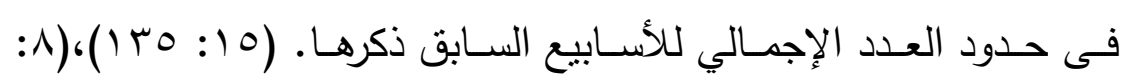

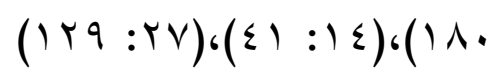

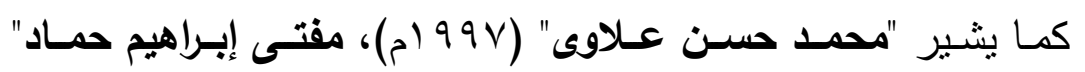

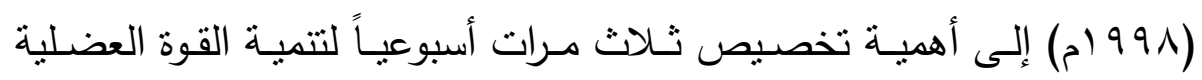

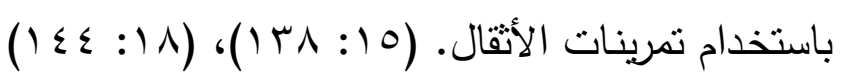

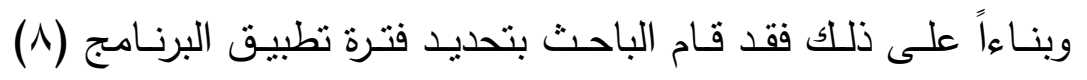

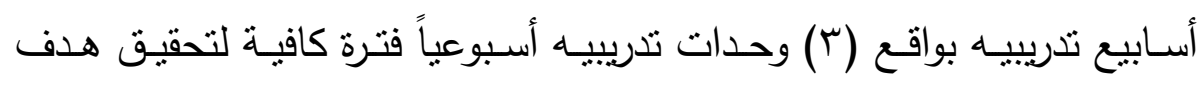
البحث.

مكونات حمل التدريب للبرنامج المقترح : * شدة الحمل : مكل الفربات

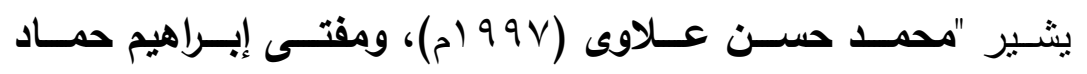

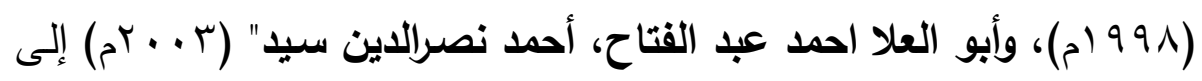

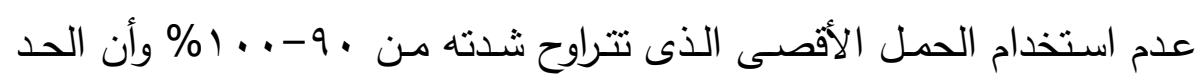
الأقصى الآمن هو من • ؟- .9\% من أقصى ما يستطيع الفرد احتماله أثناء

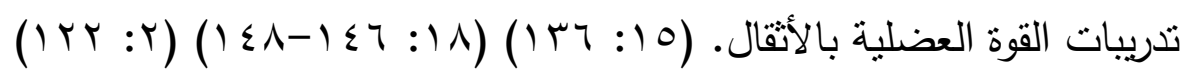

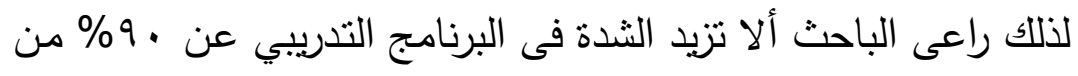
أقصى ما يستطيع الفرد تحمله.

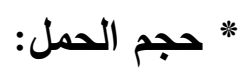

بعد الاطلاع على بعض المراجع العلمية النى تحدثت فى هذا الصدد

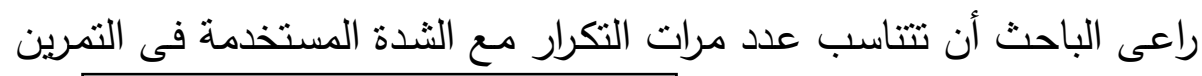
مجلة أسيوط لعلوم وفنون التربية الرياضية 
بما لا يؤدى إلى حدوث ظـاهرة الحمل الزائد حيث تراوحت عدد مرات نكرار

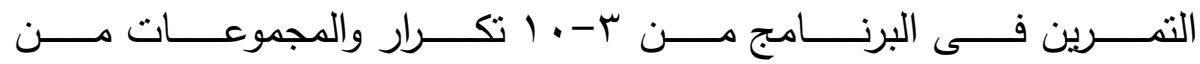

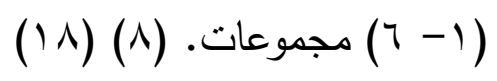

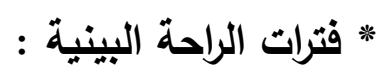

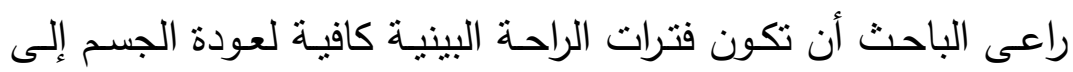

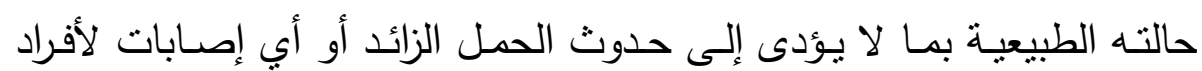
العينة.

(^) اختيار المساعدين :مرفق قام الباحث باختيار مجموعة من المساعدين من اعضاء هيئة التدريس والمعاونين من كليات التربية الرياضية والطب والعلوم للمسـاعدة فى قياسـات البحث وتطبيق البرنامج التدريبى المقترح. الاراسة الاستطلاعية:

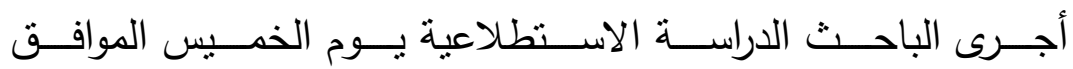

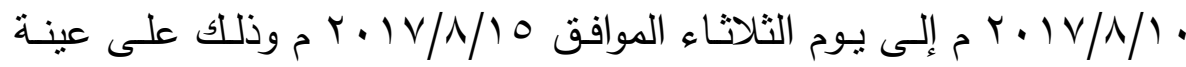
الدراسة الاستطلاعية بهدف التعرف على مدى ملائمة تدريبات البرنامج المقترح

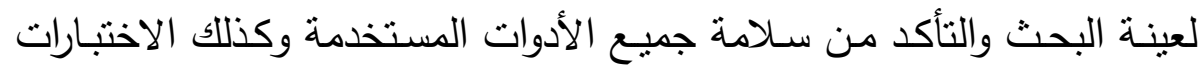

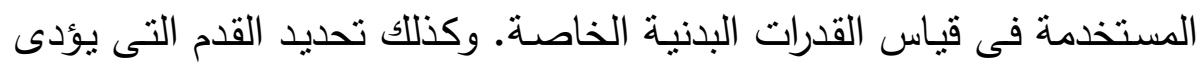

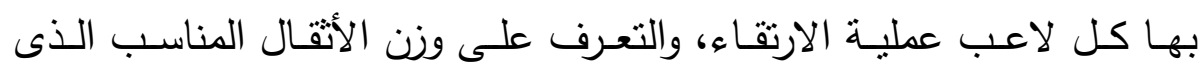

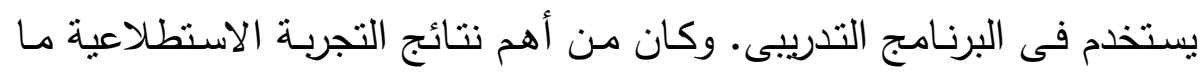
يلي: ملائكة البرنامج التدريبى لقدرات افراد عينة البحث. تم التأكد من الأدوات المستخدمة فى الاختبارات التى تقيس القدرات البدنية الخاصة.

تم تحديد قدم الارتقاء لـى كل فرد من أفراد عينـة البحث (اثتـاء عمل

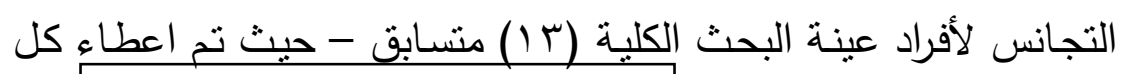
مجلة أسيوط لطوم وفنون التربية الرياضية حلمية 
لاعب 7 محاولات للتعرف على القدم المستخدمة فى عملية الارتقاء وذلك لإجراء قياس كثافة العظام لهذه القدم وتم التوصـل إلى أن قدم الارتقاء للدى جميع أفراد عينـة البحث هـى (القدم اليمنىى). وعلى حسـب نتائج

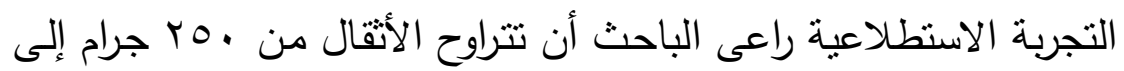

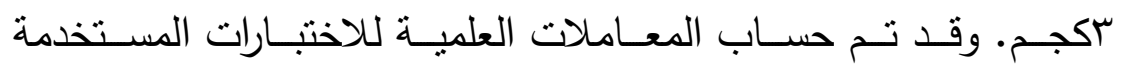
(الصدق - الثبات) والجدولين التاليين يوضحان ذلك:

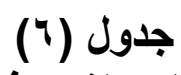

معامل الثبات بين التطبيقين الأول والثانى في المتغيرات البدنية والمستوى

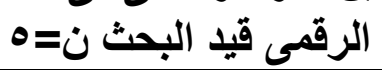

\begin{tabular}{|c|c|c|c|c|c|c|}
\hline \multirow{2}{*}{ الارتباط } & \multicolumn{2}{|c|}{ التطبيق الثانى } & \multicolumn{2}{|c|}{ التطبيت الأول } & \multirow[b]{2}{*}{ وحدة } & \multirow[b]{2}{*}{ المتغيرات } \\
\hline & الانحراف & الحتوسط & الانحراف & الحتوسط & & \\
\hline$* . . \wedge 9 \wedge$ & $\cdots 7$ & 7.19 &. .0 & $7 . \leqslant 1$ & ثانية & العدو • ممتر من المنخفض \\
\hline$* .9 . r$ &. .0 & $1 . \wedge 1$ & $\cdots \varepsilon$ & $1 . \wedge$. & سم & الوثب العريض من \\
\hline$* .949$ & 1.01 & 71.0. & 1.AV & $7 \wedge .$. & تقل/كجم & قوة عضلات \\
\hline$* .971$ & $1.0 r$ & Tr.q. & $1 . \mu$. & Tr.Y. & سم & الوثب العمودى من \\
\hline$* . \wedge 94$ & $\cdots v$. & $11.0 r$ & $\cdots \wedge$. & $11 . \varepsilon$. & متز & اللوثبت الثناتى الرقمى \\
\hline
\end{tabular}

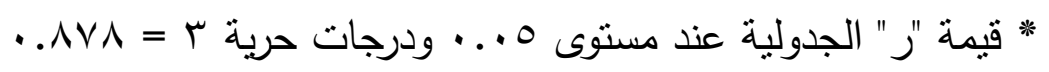

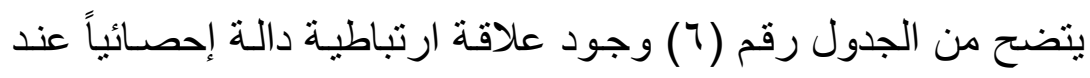

مسـتوى معنويـة ه . . • بـين قياسـات التطبيـق الأول و الثـانى للاختبـار ات قيــ

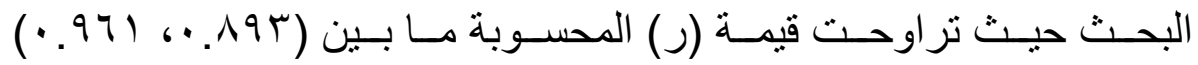
وجميعها اكبر من قيمة (ر) الجدولية مما يدل على ثبات هذه الاختبار ات.

$$
\text { جدول (v) }
$$


دلالة الفروق بين المجموعة المميزة والمجموعة الغير مميزة فى المتغيرات

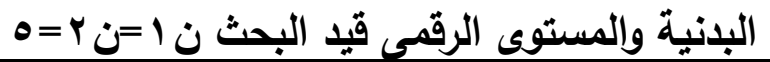

\begin{tabular}{|c|c|c|c|c|c|c|}
\hline \multirow{2}{*}{ "تيمة } & \multicolumn{2}{|c|}{ المجموعة غيز } & \multicolumn{2}{|c|}{ المجموعة المميزة } & \multirow{2}{*}{ القياس } & \multirow{2}{*}{ المتغير ات } \\
\hline & الانحريارى افت & الحستوسطى & الالحعراف & الحستوسط & & \\
\hline$*$ *.9 & $. .1 \leq$ & $7.7 \mathrm{~V}$ &. .0 & $7 . \leqslant 1$ & ثانية & العدو المنخفضر من \\
\hline$* \varepsilon .0 \mathrm{~V}$ &. .99 & 1.7. & $\cdots \varepsilon$ & 1.1. & سم & الوثب العريض من \\
\hline$* \wedge . \leqslant q$ & T.00 & $07 . .$. & $1 . \wedge V$ & १^... & نقل/كجم & قوة عضلات \\
\hline$* 0 . \Gamma \leq$ & $1 . r$. & r^.^. & $1 . r$. & Tr.r. & سم & الوثب العمودى من \\
\hline$*$ T. $\leqslant \leqslant$ &. .11 & 9.00 & $\cdots \wedge$. & $11 . \varepsilon$. & منز & اللوثبتوى الثناتلىى \\
\hline
\end{tabular}

* قيمة "ت" الجدولية عند مستوى 0 . . • ودرجات حرية 1 = اس. يتضـح مـن جـدول (V) أن هنـالك فـروق ذات دلالــة إحصــائية بـين المجموعـة المميزة والمجموعـة الغير مميزة فـى المتغيرات قيد البحث ولصـالح المجموعة المميزة وهذا يدل على أن الاختبـارات المستخدمة صسالحة للنطبيق

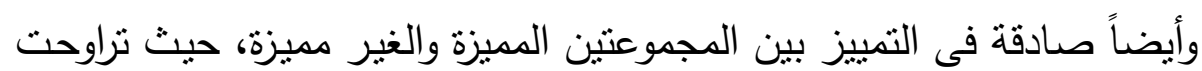

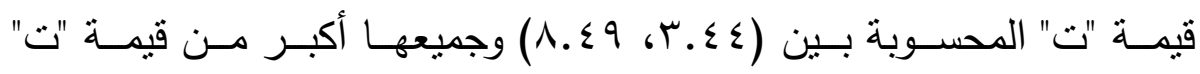
الجدولية. 


\section{تنفيذ تجربة البحث : البه}

القياسات القبلية :

أجريت القياسات القبلية على عينة البحث فى إستاد جامعة الزقازيق يوم

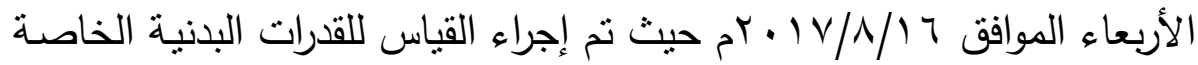

وكذللك قياس المستوى الرقمى للوثب الثلاتى لأفراد عينـة البحث وفى اليوم التالى تم إجراء القياسـات الخاصـة بمكونـات التركيب الجسـى بواسطة جهاز تانيتا (Tanita410 TBF) وكذلك قياس المتغيرات الخاصـة بكثافة معادن عظام قدم الارتقاء وذلك بمعامل المستشفى الجـامعى بكليـة الطب، جامعـة

\section{التجربة الأساسية:}

تم تطبيق البرنامج التدريبى المقترح للتدريب المركب (بلومنرك، أثقال)

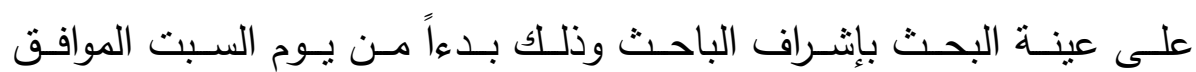
9 القياسات البعدية : البية

أجريت القياسات البعديـة على عينة البحث فى إستاد جامعة الزقازيق

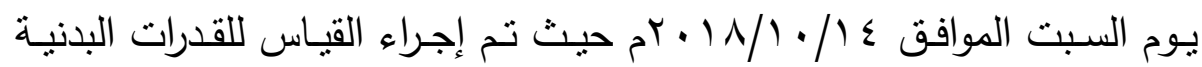
الخاصة وكذلك قياس المستوى الرقمى للوثب الثناثى لأفراد عينة البحث وفى أنى

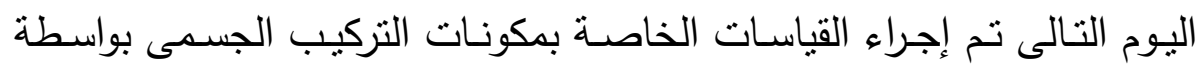
جهاز تانيتـا Tanita410 TBF) وكذللك قياس المتغيرات الخاصـة بكثافة معادن عظام قدم الارتقاء وذلك بمعامل المستشفى الجامعى بكلية الطب،

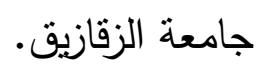

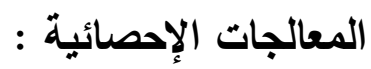
استخدم الباحث المعالجة الإحصائية المناسبة لطبيعة بحثه، حيث تم استخدام العمليات الإحصائية التالية : مجلة أسيوط لطوم وفنون التربية الرياضية 
- الانحراف المعيارى.

- معامل التفلطح.

- معامل الارتباط.

- نسب التحسن المئوية.
- المتوسط الحسابى.

- الوسيط.

- معامل الالتواء.

- اختبار " ت" تصني

عرض النتائج ومناقشتها :

أولاً: عرض النتائج:

\section{جدول (1)}

دلالة الفروق بين القياس القبلى والبعدى فى القدرات البدنية والمستوى الرقمى

$$
\text { قيإ البحث ن في في }
$$

\begin{tabular}{|c|c|c|c|c|c|c|c|}
\hline \multirow{2}{*}{ قيمة"ت" } & \multirow{2}{*}{ متوسط } & \multicolumn{2}{|c|}{ القياس البعدى } & \multicolumn{2}{|c|}{ القياس القبلى } & \multirow[b]{2}{*}{ وحدة القياس } & \multirow[b]{2}{*}{ المتغيرات } \\
\hline & & الالمعراف & المتوسط الحسب & الالمعراف & الالمتوسط & & \\
\hline$* 9.9 \mathrm{~V}$ & . & $\cdot .1$ & $7.1 \%$ &. .0 & $7 . \leq 1$ & ثانية & م العنز من البدو \\
\hline$* \vee .91$ & $. .1 \leq$ &. .7 & 1.90 & $\cdots \varepsilon$ & I.AT & سم & من العربض الثبات \\
\hline *V. Yᄉ & $7 .$. & עr.r & VT.Yo & Y.YO & $7 V .0 \leq$ & ثقل/كجم & عضلات \\
\hline$* \nearrow . \wedge\urcorner$ & 0.0. & 1.94 & rq... & I. . & גז."ז & سم & من العمودى الثبات \\
\hline *ร.ऍ人 & I.YY & $\ldots 0$ & Ir.Tr & $\cdots \wedge$. & $11 . \varepsilon$. & متر & 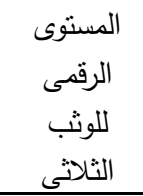 \\
\hline
\end{tabular}

* قيمة "ت" الجدولية عند مستوى 0 . . . ودرجات حرية V = דr. 
يتضـح من جدول (^) وجود فروق ذات دلالـة إحصـائية بين القياس

القبلى والقياس البعدى لعينة البحث ولصالح القياس البعدى فى جميع القدرات

البدنية الخاصة والمستوى الرقمى للوثب الثناثى.

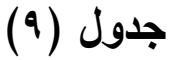

نسب التحسن المئوية في القدرات البذنية والمستوى الرقمى قيد البحث

\begin{tabular}{|c|c|c|c|}
\hline \multirow{2}{*}{ التحسن \% } & \multicolumn{2}{|c|}{ عينة البحث } & \multirow{2}{*}{ المتغيرات } \\
\hline & متوسط القياس البعدى & متوسط القياس القبلى & \\
\hline$\varepsilon .7$. & $7.1 \mathrm{r}$ & $7 . \varepsilon 1$ & العدو • ممتر من البدء المنخفض \\
\hline$\Lambda . . r$ & 1.90 & $1 . \wedge r$ & الوثب العريض من النبات \\
\hline 1.9Y & VT.YO & $7 V .0 \leq$ & قوة عضلات الرجلين \\
\hline $17 . \leqslant 1$ & rq... & 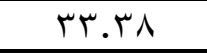 & الوثب العمودى من الثبات \\
\hline 11.15 & $1 Y .74$ & $11 . \varepsilon$. & المستوى الرقمى للوثب الثثلاتي \\
\hline
\end{tabular}

يتضـح مـن جـول (9) وجـود فـروق فـى نسـب التحسـن المئويـة بـين

القياسين القبلى والبعدى لعينة البحث ولصالح القياس البعدى فى جميع القدرات

البدنية الخاصة والمستوى الرقمى للوثب الثلاثىى .

$$
\text { جدول (1.) }
$$

دلالة الفروق بين القياسين القبلى والبعدى فى مكونات التركيب الجسمى لاىى

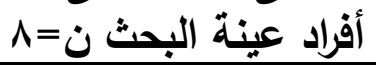

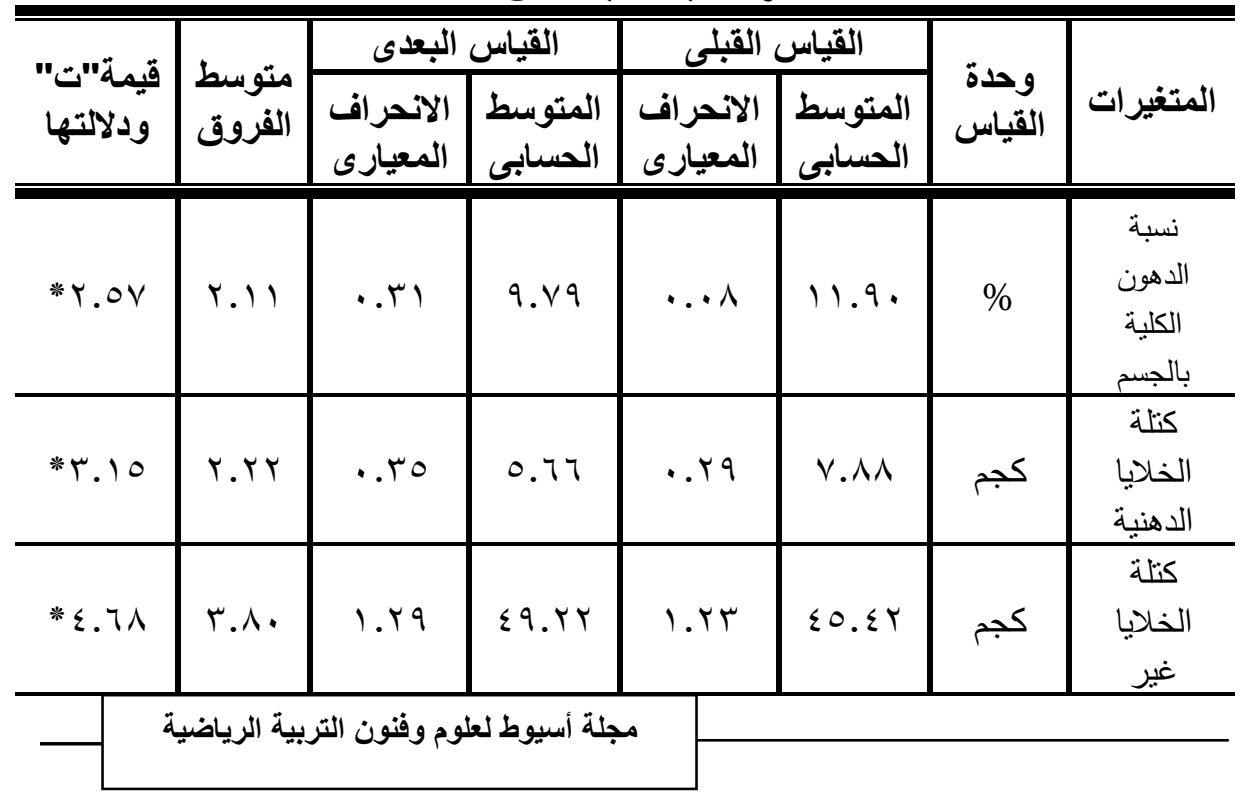




\begin{tabular}{|c|c|c|c|c|c|c|c|}
\hline & & & & & & & الدهنية \\
\hline *V.rq & $1 . \leqslant \wedge$ &.$\wedge \varepsilon$ & 19.11 & .77 & $r \cdot .7$. & كجم/ק' & مؤشر كتلة \\
\hline
\end{tabular}

$$
\text { قيمة "ت" الجدولية عند مستوى } 0 \text {. . . ودرجات حرية = بس. }
$$

يتضح من جدول (• (1) وجود فروق ذات دلالة إحصائية بين القياس القبلى

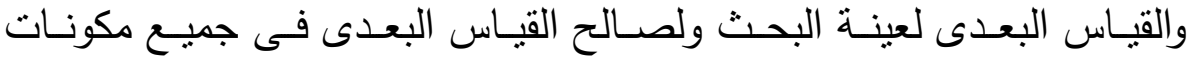

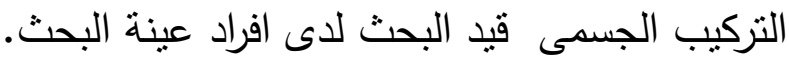

$$
\text { جدول (11) }
$$

\begin{tabular}{|c|c|c|c|}
\hline \multirow{2}{*}{ التحسبة\% } & \multicolumn{2}{|c|}{ عينة البحث } & \multirow[b]{2}{*}{ المتغيرات } \\
\hline & متوسط القياس & متوسط القياس & \\
\hline 11.1. & 9.19 & 11.9. & نسبة الدهون الكلية بالجسم \\
\hline 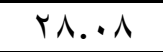 & 0.77 & $\vee . \wedge \Lambda$ & كتلة الخلايا الدهنية \\
\hline A.. 9 & $\sum q . Y Y$ & $\sum 0 . \varepsilon Y$ & كتلة الخلايا غير الدهنية \\
\hline$v_{.} \cdot v$ & $19.1 \mathrm{r}$ & r..T. & مؤشر كتلة الجسم الكلية \\
\hline
\end{tabular}

نسب التحسن المئوية في فى مكونات التركيب الجسمى لاى أفراد عينة البحث

يتضـح مـن جدول (1) (1) وجـود فروق فى نسـب التحسن المئويـة بين

القياسين القبلى والبعدى لعينة البحث ولصالح القياس البعدى فى جميع مكونات التركيب الجسمى الجسمى قيد البحث لاى افراد عينة البحث.

$$
\text { جدول (Y) }
$$

\begin{tabular}{|c|c|c|c|c|c|c|c|}
\hline \multirow{2}{*}{ قيمة"ت" ودلتها } & \multirow{2}{*}{ الفروق } & \multicolumn{2}{|c|}{ القياس البعدى } & \multicolumn{2}{|c|}{ القياس القبلى } & \multirow[b]{2}{*}{ والقياس } & \multirow[b]{2}{*}{ المتغيرات } \\
\hline & & الالنحراف & المتوسط الحسى & الالمعراف & المتّابي & & \\
\hline *9.7 &. .17 &. .0 & 1.11 & ...r & $1 . .19$ & $\mathrm{~g} / \mathrm{cm}^{2}$ & $\begin{array}{c}\text { BMD } \\
\text { عنق عظل الفخذ }\end{array}$ \\
\hline$* 1 . \wedge \wedge$ &. .7 &..$r$ &. $.9 r r$ & $\ldots 0$ &. $.10 \mathrm{~V}$ & $\mathrm{~g} / \mathrm{cm}^{2}$ & BMD \\
\hline
\end{tabular}

دلالة الفروق بين القياس القبلى والبعدى فى كثافة وكتلة معادن عظام قدم

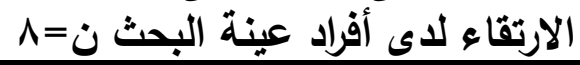




\begin{tabular}{|c|c|c|c|c|c|c|c|}
\hline & & & & & & & الكبير \\
\hline$* V . r V$ & .1 & $\cdots \leqslant$ & $\cdot \wedge \leq 1$ & $\cdots \wedge$ & $\Rightarrow V \varepsilon \varepsilon$ & $\mathrm{g} / \mathrm{cm}^{2}$ & $\begin{array}{c}\text { Words } \\
\text { Tri } \\
\text { BMD }\end{array}$ \\
\hline$* 7.70$ & . &.$\leqslant 0$ & $0 . V V$ & . & $\varepsilon . \varepsilon V$ & $\mathrm{~g}$ & $\begin{array}{c}\text { BMC } \\
\text { عنق عظّ الفخذ }\end{array}$ \\
\hline$* r .09$ & דr.. & ז". & 11.99 & $\cdots \wedge$ & 11.7 & $\mathrm{g}$ & $\begin{array}{r}\text { BMC } \\
\text { الكدور } \\
\end{array}$ \\
\hline$* 0 . \leqslant Y$ & $\ldots 9$ & $\cdots \varepsilon$ &.$\wedge 9$ & $\cdots 1$ &.$\wedge$ & $\mathrm{g}$ & $\begin{array}{c}\text { Words } \\
\text { Tri } \\
\text { BMC }\end{array}$ \\
\hline
\end{tabular}

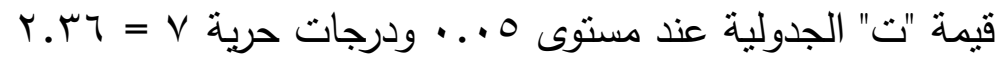

يتضـح من جدول (Y I) وجود فروق ذات دلالـة إحصـائية بين القباس

القبلى والقياس البعدى لعينة البحث ولصسالح القياس البعدى فى متغيرات كثافة وكتلة معادن عظام قدم الارثقاء قيد البحث.

جدول (i (i)

نسب التحسن المئوية فى كثافة وكتلة معادن عظام قدم الارثقاء لاثى أفراد عنية البحث

\begin{tabular}{|c|c|c|c|}
\hline \multirow{2}{*}{ التحسنة\% } & \multicolumn{2}{|c|}{ عينة البحث } & \multirow[b]{2}{*}{ المتغيرات } \\
\hline & متوسط القياس & متوسط القياس & \\
\hline $10 . . V$ & 1.11 & $1 . .19$ & BMD عنق عظم الفخذ \\
\hline V.VI & $.9 r r$ &. $.10 \mathrm{~V}$ & BMD المدور الكبير \\
\hline IT.YY & $. . \wedge \leqslant 1$ & $. V \leq \varepsilon$ & Words Tri BMD \\
\hline$r \wedge . \cdot V$ & $0 . V V$ & $\varepsilon . \varepsilon V$ & عنق عظد الفخذ BMC \\
\hline r.. T & 11.99 & 11.74 & BMC المدور الكبير BMC \\
\hline Q.YY &. .19 &.$\wedge$. & Words Tri BMC \\
\hline
\end{tabular}

مجلة أسيوط لعلوم وفنون التربية الرياضية 
يتضح من جدول رقم (r I ) وجود فروق فى نسب التحسن المئوية بين

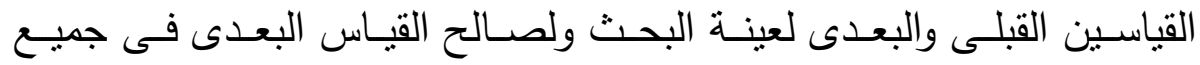
متغيرات كثافة وكتلة معادن عظام قدم الارتقاء قيد البحث. ثانياً: مناقشة النتائج: 1- مناقشة النتائج الخاصة بالهذف الأول:

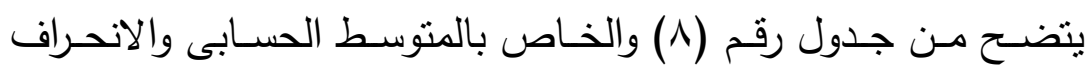

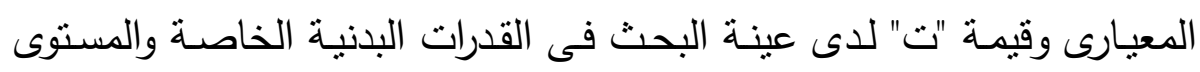

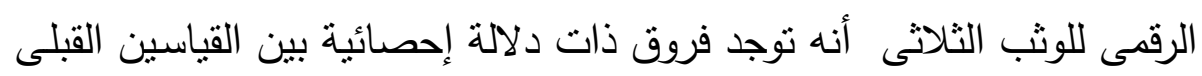

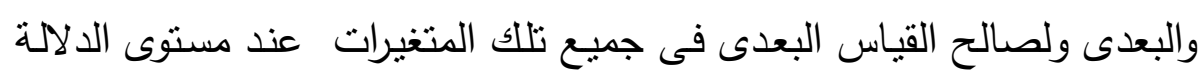

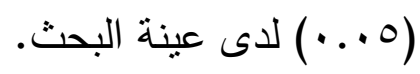

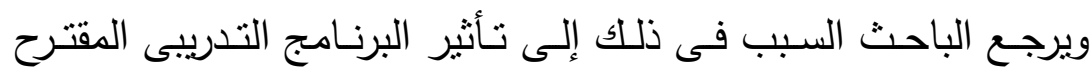

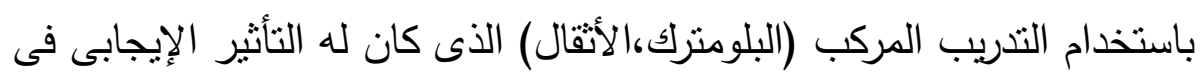

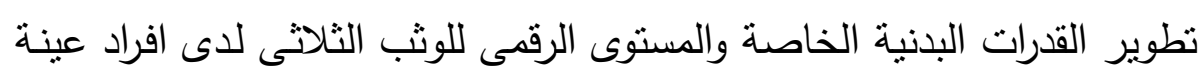

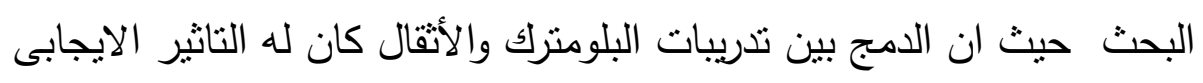

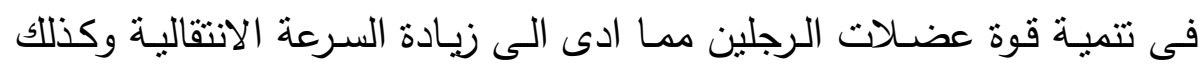

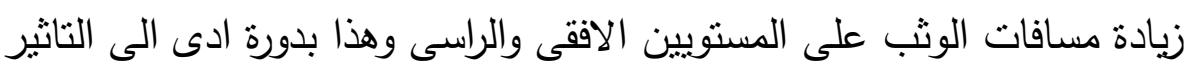

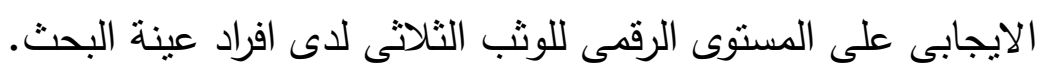

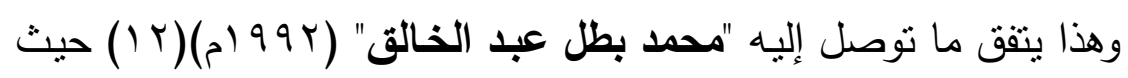

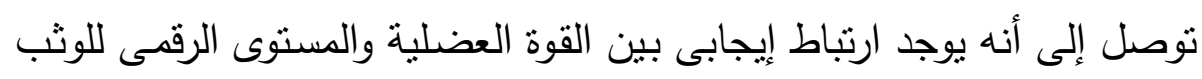

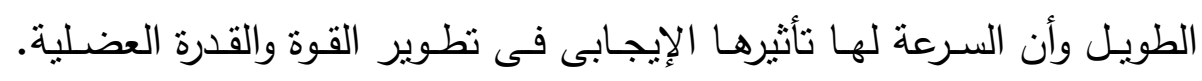

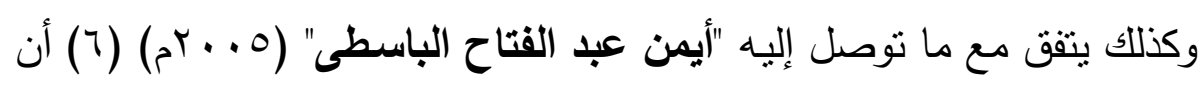

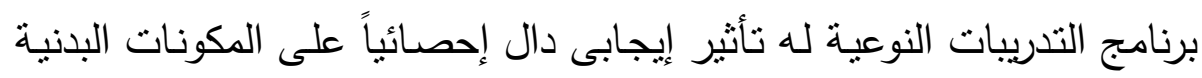

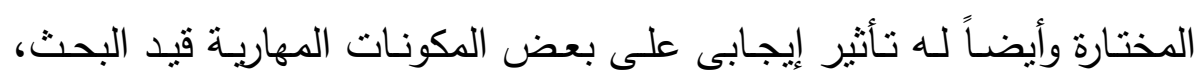

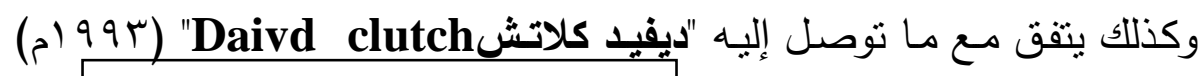
مجلة أسيوط لعلوم وفنون التربية الرياضية 


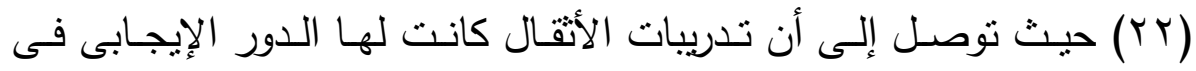

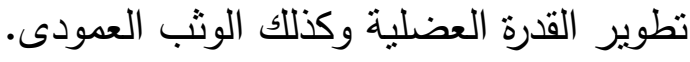

كمـا يوضـح الجدول رقم (9) والخـاص بنسـب التحسن فـى القدرات الخاصـة والمستوى الرقىى للوثب الثلاثىى لـى عينـة البحث أنه نوجد نسب

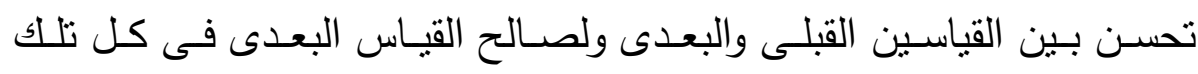
المتغيرات وكذللك المستوى الرقمى للوثب الثناثى.

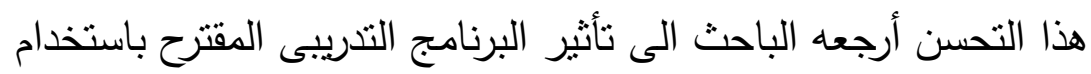

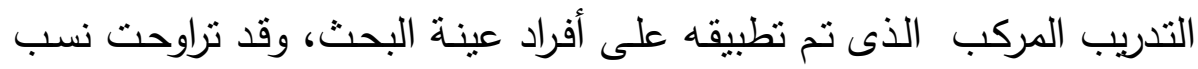

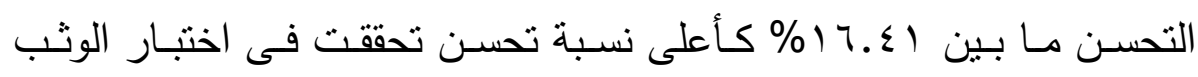

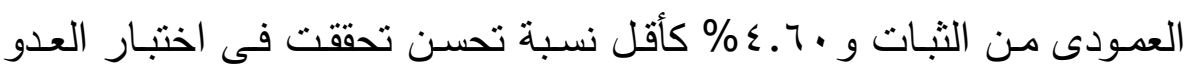

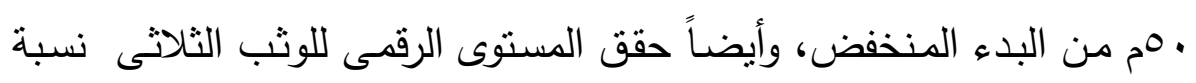

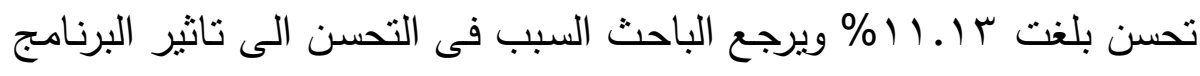

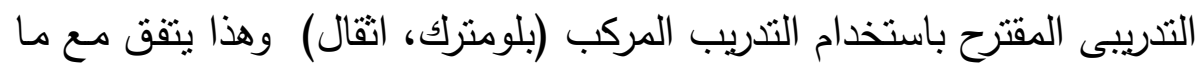

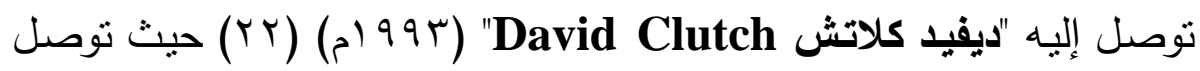

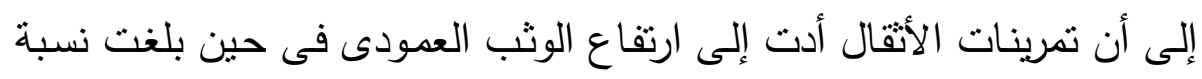

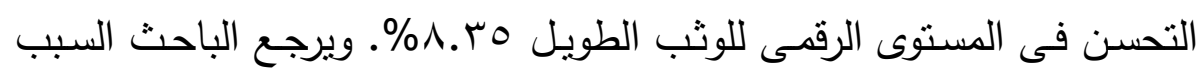

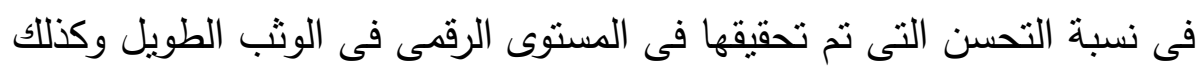

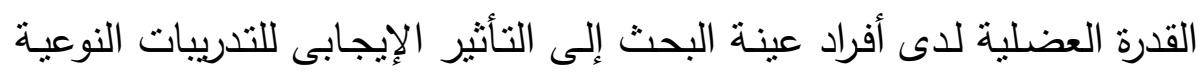

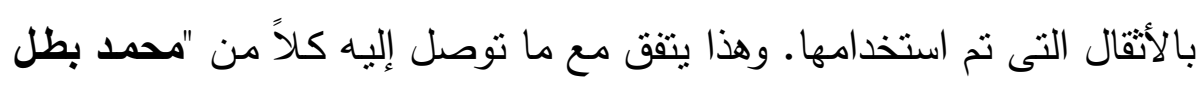

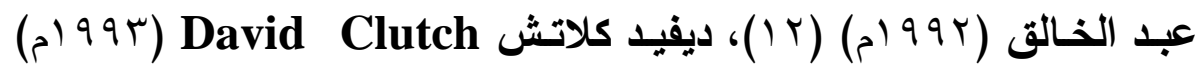

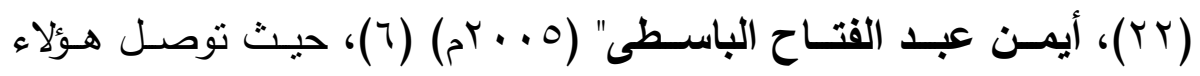

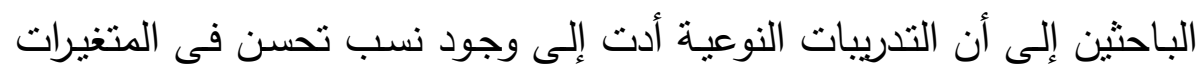
البدنية والنواحي المهارية قيد أبحاثهم. 
ومن خلال ما تم عرضه فى الجدولين (^)،(9) يتحقق الفرض الأول الذى (ألى ينص على أنه "يؤثر التدريب المركب تأثيرا ايجابيا على بعض القدرات البذنية والمستوى الرقمى للوثب الثثلاثى لاى أفراد عينة البحث".

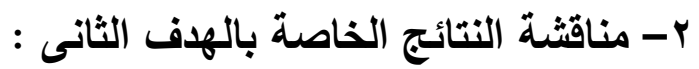
يتضـح من جدول رقم ( • () والخـاص بالمتوسط الحسـابى والانحراف المعيارى وقيمة "ت" لدى عينة البحث فى مكونات التركيب الجسمى قيد البحث لدى افراد عينة البحث، أنه توجد فروق ذات دلالة إحصائية بين القباسين القبلى والبعدى ولصـالح القياس البعدى فى جميع تلك المتغيرات عند مستوى الدلالة (0)

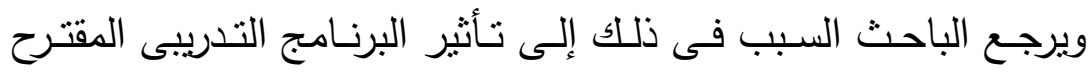
باستخدام التدريب المركب (البلومنرك، الأثقال) الذى كان له التأثير الإيجابى فى تطوير القدرات البدنية الخاصـة والمستوى الرقمى للوثب الثلاتى لدى افراد عينة البحث حيث ان التدريب المركب (البلومترك والأثقال) كان لـه التاثير الايجابى على مكونـات التركيب الجسمى حيث ادت الى تقليل نسبة الدهون بالجسم وزيادة الكتلة غير الدهنية وتحسن مؤشر كتلة الجسم لدى أفراد عينة البحث

وهذا يتفق ضمنياً مع ما توصل إليه "ماجد محمد العزازى" ( . . . rم) (1) أن البرنامج التدريبى أدى إلى تطوبر الكفاءة البدنية والمكونات الجسمية، كما يتفق مع ما توصل إليه "أحمد عبد الحميد علي" (T . . rم) (0) أن تتمية القدرة الهوائية وفقاً لبعض المكونات الجسمية أدت إلى تتمية التحمل وتطوير تلك المكونـات الجسمية قيد البحث، وأيضـاً يتفق ضـنياً مـع مـا نوصـل إليها

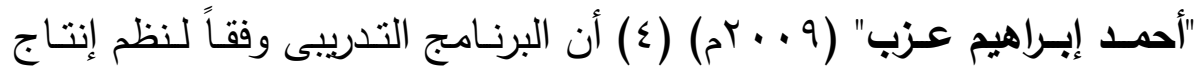
الطاقة أدى إلى تطوير بعض المتغيرات البدنيـة والتكوين الجسمى لدى عينـة 
كما يوضـح الجدول رقم (1 (1) والخـاص بنسب التحسن فى مكونـات التركيب الجسمى لدى عينة البحث أنه توجد نسب تحسن بين القياسين القبلى والبعدى ولصالح القياس البعدى فى كل نلك الكوناتحيث تراوحت نسب التحسن

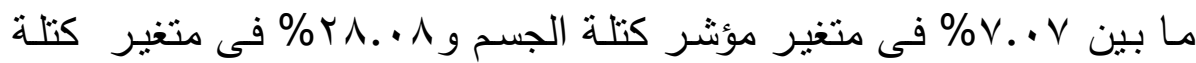

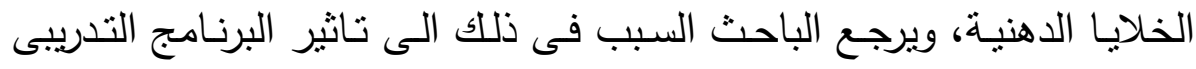
باستخدام التدريب المركب الذى ادى الى التاثير الايجابى على المتخيـرات

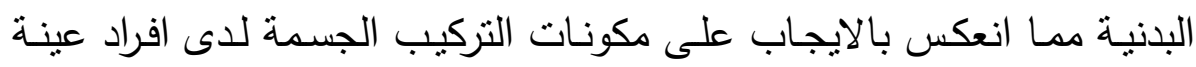

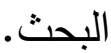

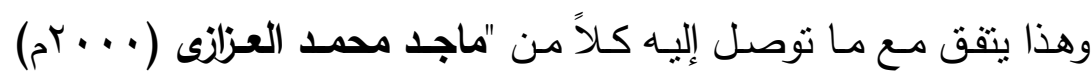

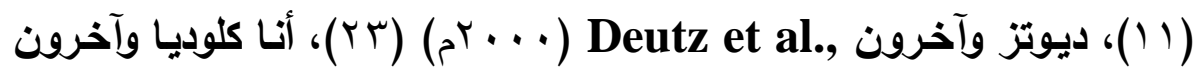
Ana Claudia et al.,

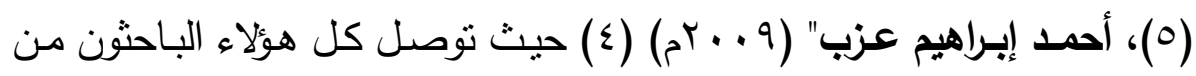

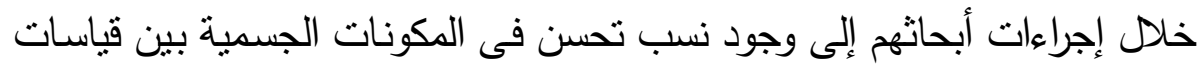
البحث ولصالح القياس الأعلى لاى عينات أبحاثهم.

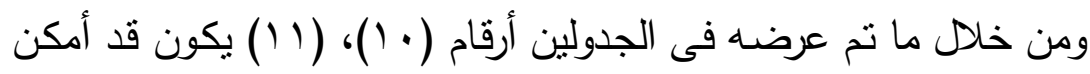
التحقق من صحة الفرض الثانى الذى نص على: "يؤثر التدريب المركب تأثيرا

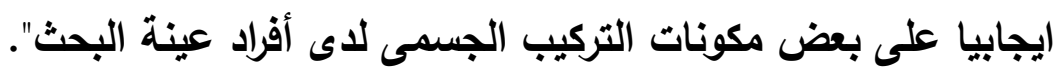

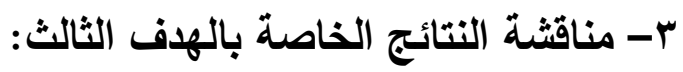

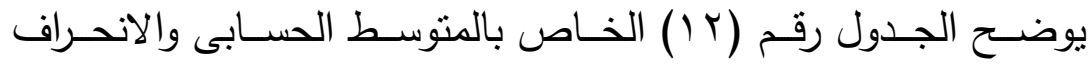
المعيارى وقيمة "ت" لعينة البحث فى المتغيرات الدالة على كثافة وكتلة معادن

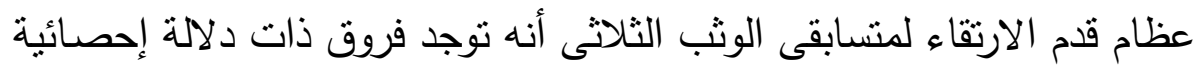
فى كل المتغيرات الدالة على كثافة وكتلة معادن عظام قدم الارتقاء وذلك بلك بين القياسين القبلى والبعدى ولصالح القياس البعدى لدى أفراد عينة البحث. 
ويعزى الباحث السبب فى وجود تلك الفروق إلى تأثثر البرنامج التدريبى المقترح باستخدام التدريب المركب والذى كان لـه التأثنير الإيجابى فى زيـادة كثافة وكتلة معادن عظام قدم الارتقاء من جراء تتمية القدرات البدنية الخاصـة لاى أفراد عينة البحث وهذا يتفق مع ما أثنار إليه "روجر Roger" (Y . . r مث) (Yr) بأن تحفيز العظام على النمو يتم عن طريق الأنشطة البدنية لما لها من مان

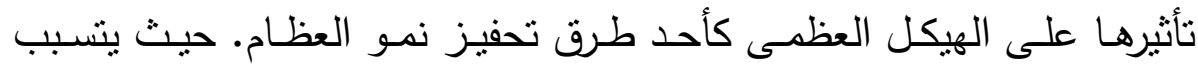
التدريب الرياضـى إلى ترسيب العظام من خلال إحداث الضغط على العظام الذى يؤدى إلى حدوث انزلاق ألياف الكولاجين واحدة تلو الأخرى وحدوث جهد كهربي سالب فى السطح المنضغط فى الجزء الأخر من العظام وعلى هذا فقد حاول العلماء والباحثين إيجاد علاقة بين الضغط الميكانيكي الواقع على العظام والتأثيرات الكهربائيـة داخل العظام لتكوين تغيرات فيزيائيـة وهذا يؤكد مـا تم مشـاهدته من كميات دقيقة من التيـارات الكهربيـة المتتاليـة داخل العظـام أثناء

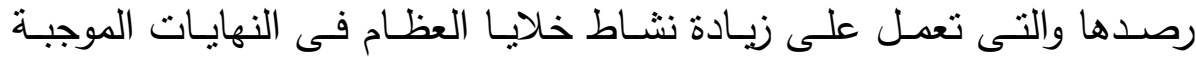
للتيارات الكهربية وتم تفسيرها على أنها تزايد فى ترسيب العظام عند مناطق حدوث الضغط.(r)

كما توصل كلاً من "أويرادوفيك كوفاسيف Obradavic Kovacev

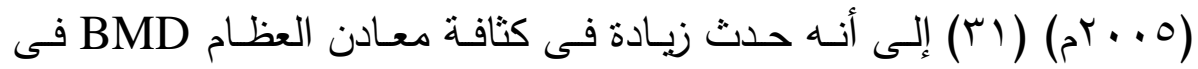
الأطراف التى يستخدمها الرياضيين فى ممارسة الأنشطة البدنية. ويتضـح من الجدول رقم (r I) والخاص بنسب التحسن فـى المتغيرات الدالة على كثافة وكتلة معادن عظام قدم الارتقاء أنه وجدت نسب تحسن فى ونى تلك المتغيرات بين القياسين القبلى والبعدى ولصـالح القياس البعدى. ويرجـ الباحث السبب فى هذا التحسن إلى تأثير البرنامج التدربيى المقترح باستخدام التدريب المركب الذى تم تطبيقه على أفراد عينة البحث وانه حدث تحسن فى البى الكثافة كرد فعل لتحسن القدرات البدنية الخاصـة والضغط الواقع الى العضلة 
اثناء اداء تدريبات البلومترك والاثقال الذى اعتمد عليهم الباحث اثناء تطبيق برنامج التندريب المركب على افراد عينة البحث.

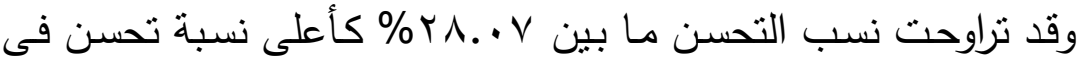

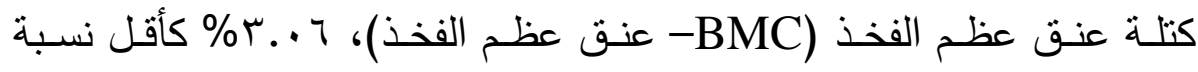

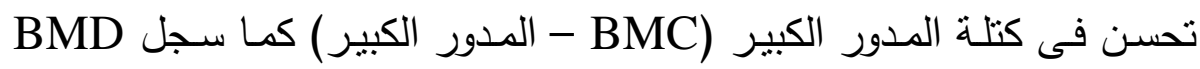

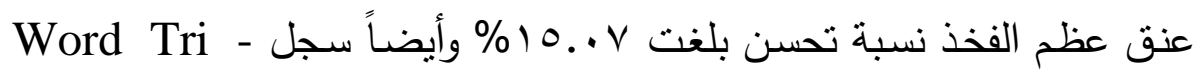

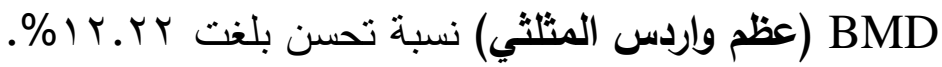

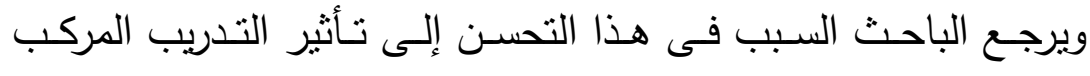
(بلومترك ،اتقال ) الذى تم استخدمه فى البرنامج التدريبى الذى تم تطبيقه على أفراد عينة البحث.

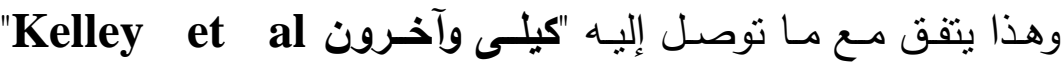

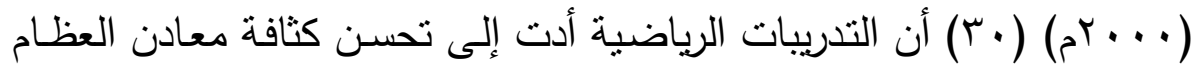

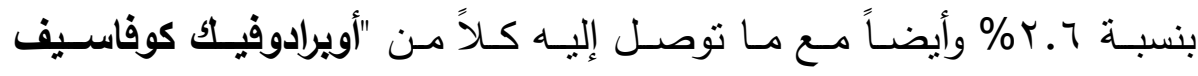
Obradovi Kovacev عظام الأطراف المستخدمة فى التدريبات لاى الرياضيين.

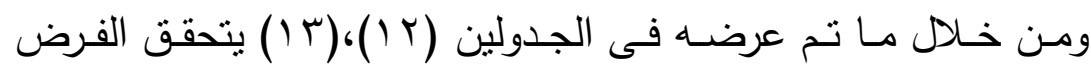
الثالث الذى ينص على أنه "يؤثر التدريب المركب تأثيرا ايجابيا على كثافة الجية

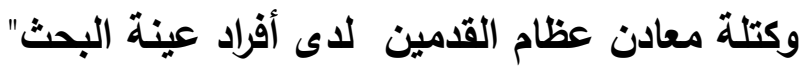

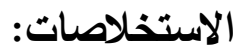

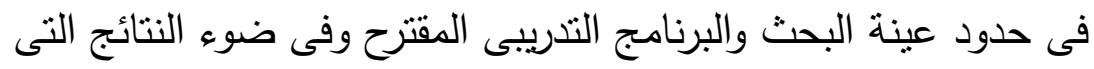
تم التوصل إليها يستتنج الباحث ما يلي: 1- التدريب المركب (بليومنزك، اثقال) يؤثر تأثنيراً إيجابياً بدلالـة احصـائية

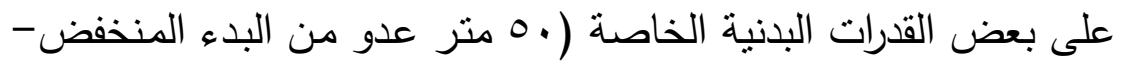


الوثب العريض من الثبات- قوة عضـلات الرجلين- الوثب العمودى من الثبات) لدى افراد عينة البحث. r- التدريب المركب (بليومترك، اثقال) يؤثز تأثنراً إيجابيـاً بدلالـة احصـائية على المستوى الرقمى للوثب الثلاتى لاى افراد عينة البحث. ب- التدريب المركب (بليومترك، اثقال) يؤثز تأثنيراً إيجابياً بدلالـة احصـائية على بعض مكونات التركيب الجسمى (نسبة الدهون الكلية بالجسم- كتلة الخلايا الدهنية- كتلة الخلايا غير الدهنية- مؤثر كتلة الجسم) لادى افراد عينة البحث. ع - التدريب المركب (بليومترك، اثقال) يؤثر تأثنيراً إيجابياً بدلالـة احصـائية على BMD (كثافة معادن عظام قدم الارتقاء) لدى عينة البحث.

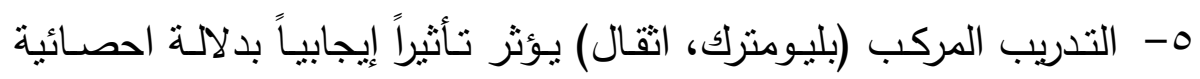
على BMC (كتلة معادن عظام قدم الارتقاء) لدى عينة البحث.

التوصيـاث : (1)

فى ضوء النتائج و الاستتناجات يوصى الباحث بما يلي:

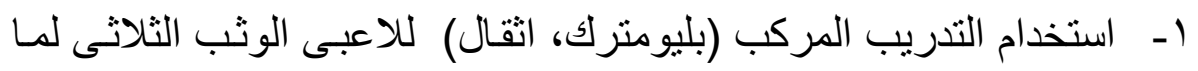
لها من أهمية فى تطوير القدر ات البدنية الخاصة و المستوى الرقمى.

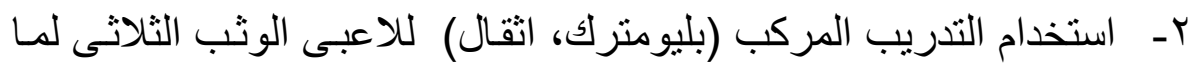

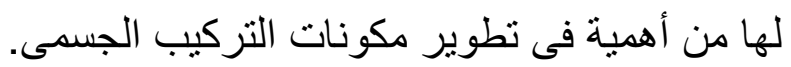

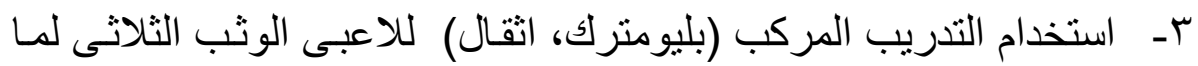
لها من أهمية فى زيادة كثافة وكتلة معادن عظام قدم الارتقاء.

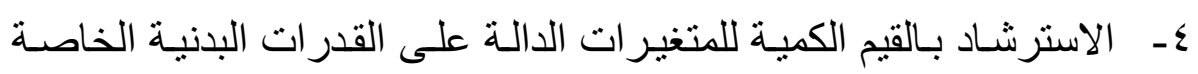

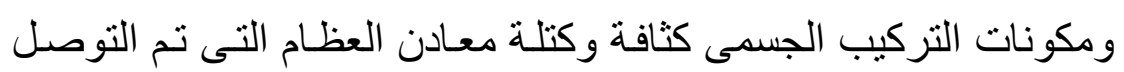
إليها فى هذا البحث لإجر اء بحوث مشابهة فى مسابقات أخرى. 


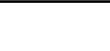

\section{أولا : المراجع العربية :}

1 - أبو العلا أحمد عبد الفتاح: بيولوجيا الرباضة وصحة الرياضي، دار الفكر

$$
\text { العربي، القاهرة، } 991 \text { (م. }
$$

r - أبو العلا أحمد عبد الفتاح، أحمد نصر الدين: فسيولوجيا اللياقة البدنية،

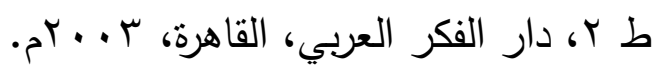

ب- أبـو العـلا أحمــ عبــ القتــاح، محمــ صـبحي حسـانين: فسـيولوجيا ومورفولوجيـا الرياضـي وطـرق القيـاس للتقويم، دار الفكـر

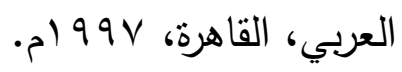

ع - أحمد إبراهيم عزب: برنامج تدريبي مقترح وفقاً لنظم أنتاج الطاقة لتحسين القدرة الهوائية واللاهوائية وبعض المتغيرات البدنية والتكوين الجسـمي للاعبـي المبـارزة، بحـث منشـور، مجلـة بحـوث

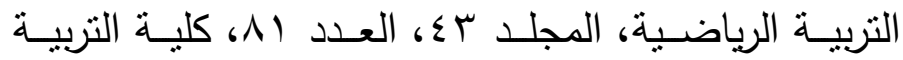

$$
\text { الرياضية للبنين، جامعة الزقازيق، } 9 \text {. . rم. }
$$

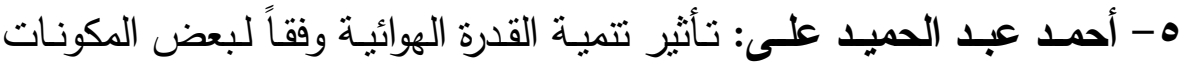
الجسـمية علـى تحمـل الأداء للاعبــي الملاكمــة، رســالة

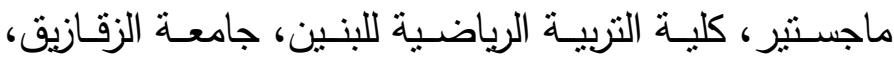

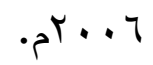

צ - أيمن أحمد عبد القتاح الباسطى: فعالية برنامج للتدربيات النوعية على آلى

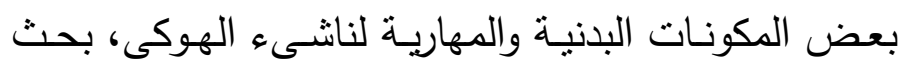

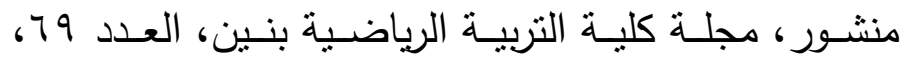

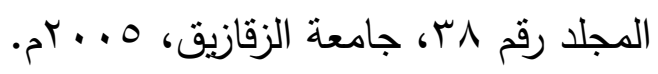

V - حسين حشـمت، نـادر شـلبي: الوراثة فى الرياضـة، مركز الكتاب للنشـر ،

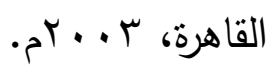


^- طلحـة حسـام الدين: الأسس الحركية والوظيفية للتندريب الرياضسى، دار

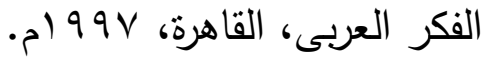

9- عبد الرحمن عبد الحميد زاهر : فسيولوجيا مسابقات الوثب والقفز ، مركز

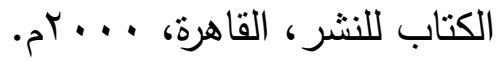

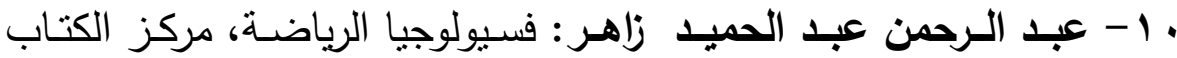

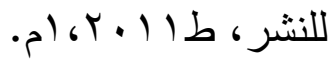

11 - ماجد محمد العزازى: تأثير برنامج تدريبي على بعض المكونات الجسمية

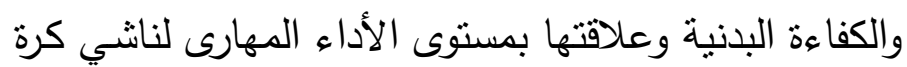

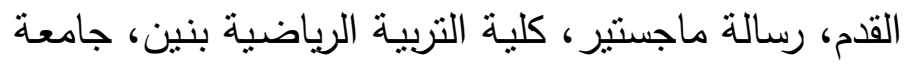

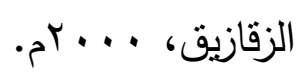

r ا - محمــ بطل عبـد الخـالق: دراسـة للقدرة العضلية لدى لاعبى الوثب التب

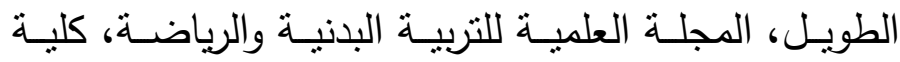

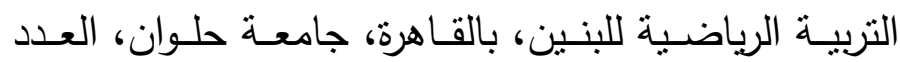

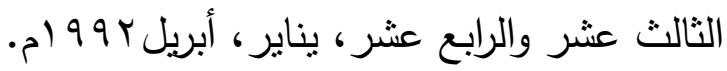
ب ا - محمد صبحى حسـانين: القياس والتقويم فى التربية البدنية والرياضـة،

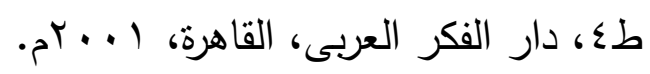

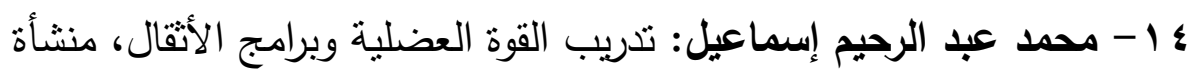

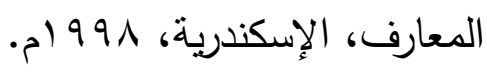

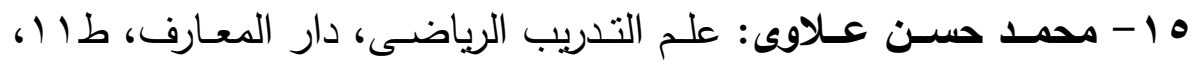

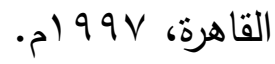

1 ا - محمد حسن علاوى، أبو العلا احمد عبد القتاح: سيكولوجية الإصابات الرياضية، مركز الكتاب للنشر ، القاهرة، 991 ام. IV - مسعد علي محمود: المدخل إلى علم التدريب الرياضى، دار الطباعة

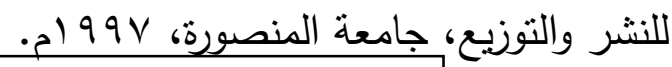
مجلة أسيوط لعلوم وفنون التربية الرياضية 
1 1 - مفتى إبراهيم حماد: التدريب الرياضى الحديث، تخطيط وتطبيق وقيادة، دار الفكر العربى، القاهرة، 991 ام.

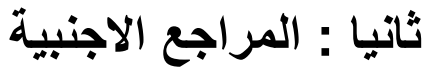

19- Admas.K: the effect of six weeks of squat plymetric and squat plyometric Training on power production, Journal of applied sport science research b.(1) Fc. march 1995.

20- Ana Claudia Fernandez et, al : Influence of the aerobic and anaerobic training on the body fat mass in obese adolescents, Rev Bras Med Esporta - Vol 10 , N3 - Mai / Jun.2004.

21- Christopher, M.N :Weigh training Principle, practice, A, Black publishing London, 1996.

22- David clutch : The Effect of Depth jump and vertical jump on vertical spacing jump and power legs, RQ. vol ,1993.

23- Deutz, Rc.Bernard-T-Det et al.: Relationship between angenry and body composition in elite female gymnastics and runners. Georgia state university. Atlanta a30303 united stat co. of America 2000.

24- Donold chu,: Explosive power, Strength complex Training for Maximum results canada1996. 
25- Donold chu,: Explosive power, Strength complex Training for Maximum result can human kinetics, London 2000

26- Ebben willam: complex training obrief review ,journal of sport science and medicine 1-42,46 -2002.

27- Flikck SJ, Kramer: Dsigning Resistance Training program $3^{\text {rd }}$ ed Human kinetics cham paing, Newyork, USP, 2004.

28- Herm, P: Koeperfett messung, standers der sportmedizin deutsch zeitsschrift fuer sportmedizin jahrgang 54, nr.5 deutschland, 2003.

29- Jackson, A.,: Reliability and body composition , journal of applied physiology, Vol 55 , No 2, 1998.

30- Kelley et al: Exercise and bone: minerals density in men ameta analysis, Journal of applied Physilogy, vol 88, Lssues May 2000.

31-Obradovic Kovacev: Bone Minerals density of calcaneus and dominat lower limb, faculty of Physical education ,University of Novisad, SCG,2005.

32- Roger A.: Neuromecthanics of human morment third edition ,Human Kinetic, 2002. 


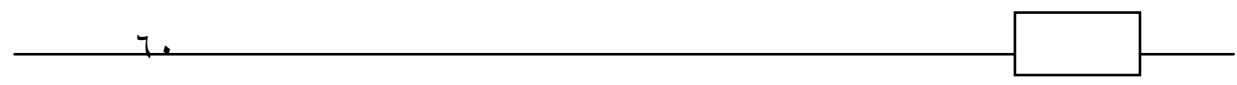

33- Thomas R. Beachle et al: Essentials of strength training and conditioning second edition, Human kinetics 2000.

34- www.dr.squatu.htm

35- www.answers.com/topic/chemistry

36- www.nmsu-alamogordoeud

37- www. Tanita-scale.com/pro.scales/tbf410.html)

مجلة أسيوط لعلوم وفنون التربية الرياضية 